UNIVERSIDADE DE BRASÍLIA

INSTITUTO DE CIÊNCIA POLÍTICA

PROGRAMA DE PÓS-GRADUAÇÃO EM CIÊNCIA POLÍTICA

Marcela Machado

O QUE O DINHEIRO COMPRA? A RESPONSIVIDADE DO CONGRESSO

NACIONAL FRENTE AO FINANCIAMENTO DE CAMPANHAS DA

INDÚSTRIA

Brasília

2016 
Marcela Machado

O QUE O DINHEIRO COMPRA? A RESPONSIVIDADE DO CONGRESSO

NACIONAL FRENTE AO FINANCIAMENTO DE CAMPANHAS DA

INDÚSTRIA

Dissertação apresentada ao Programa de Pós-Graduação em Ciência Política do Instituto de Ciência Política da Universidade de Brasília como requisito parcial para a obtenção do título de Mestra em Ciência Política.

Orientador: Prof. Dr. Lucio Remuzat Rennó Junior 


\section{O QUE O DINHEIRO COMPRA? A RESPONSIVIDADE DO CONGRESSO NACIONAL FRENTE AO FINANCIAMENTO DE CAMPANHAS DA INDÚSTRIA}

Dissertação apresentada como requisito parcial para a obtenção do título de Mestra em Ciência Política pela Universidade de Brasília e avaliada pela seguinte banca examinadora:

PROFESSOR DOUTOR LUCIO REMUZAT RENNÓ JUNIOR

(Universidade de Brasília)

PROFESSOR DOUTOR DAVID VERGE FLEISCHER

(Universidade de Brasília)

PROFESSOR DOUTOR RAFAEL SILVEIRA E SILVA

(Senado Federal)

PROFESSORA DOUTORA SUELY MARA VAZ GUIMARÃES DE ARAÚJO

(Suplente)

Brasília

2016 
Àqueles que me serviram de exemplo, estímulo e sustentáculo durante este percurso. Principalmente, aos meus queridos pais, que nunca mediram esforços para que os meus sonhos se tornassem realidade. 


\section{AGRADECIMENTOS}

If I have seen further, it is by standing on the shoulders of giants.

Isaac Newton

Sou grata a Deus, em primeiro lugar, por todas as bênçãos e realizações em minha vida. Sem Ele, nada disso seria possível.

Ao meu pai e à minha mãe, obrigada pela paciência. Agradeço por sempre me apoiarem em todas as minhas escolhas, por me orientarem nestas e, principalmente, por acreditarem e investirem nos meus sonhos, como se seus fossem.

Aos amigos, que por muitas vezes atuaram no papel de irmãos: Fernando Crosara, Mateus Lôbo, Milton Mendonça, Felipe Portela e Noëlle Silva. Obrigada pelo apoio, pelo amparo, pela motivação, pelas broncas e por comemorarem comigo as minhas vitórias.

Ao meu eterno colega de faculdade, parceiro acadêmico, coautor e amigo, Eduardo Barbabela. Obrigada por continuar sendo o meu braço direito e por topar entrar comigo em todas as empreitadas acadêmicas. Parte desse sucesso também é seu!

Ao meu orientador, professor Lucio Rennó, agradeço por confiar em mim e por acreditar no meu potencial. É motivo de muito orgulho tê-lo, mais uma vez, como meu mentor.

À professora Suely Araújo, por trazer luz aos dias que pareciam nublados. Obrigada por ter atuado como mais que uma professora, mas também como mãe e conselheira. A oportunidade de ter lecionado ao seu lado no estágio-docência fez com que a minha experiência acadêmica ganhasse mais sentido. Ao professor David Fleischer, por ter gentilmente aceitado o convite para compor a banca examinadora e por trazer grandiosas contribuições a esta dissertação. É uma honra contar com o apoio de um professor com tamanha envergadura intelectual. Ao professor Rafael Silveira, por todo o auxílio com a parte metodológica desta dissertação. Obrigada pela paciência e, principalmente, por ter tornado o universo da QCA mais palatável. Aos professores 
Adrián Albala (NUPPs/USP) e Manoel Santos (DCP/UFMG), por me auxiliarem, via $e$ mail, em todas as dúvidas e questionamentos.

À secretaria do IPOL, principalmente ao Fábio Sousa, Dina Almeida e Thaynara Bandeira. Vocês são peças-chave dentro do Instituto. Obrigada por sempre socorrerem esta pós-graduanda e também pelos momentos de descontração, no intervalo dos estudos.

Agradeço, também, a CAPES, pelo auxílio financeiro. Ser pesquisadora é uma tarefa onerosa, em vários sentidos. Porém, muito prazerosa e recompensadora.

E a todos aqueles que, mesmo não expressamente mencionados, também fazem parte desta conquista. Sou muito grata pelo amparo, pela atenção, pela colaboração e pela compreensão ao longo desta trajetória.

"Se vi mais longe, foi por estar sobre os ombros de gigantes". 


\title{
RESUMO
}

A interferência dos interesses privados e corporativistas nas agendas de governo, bem como os mecanismos utilizados para influenciarem as políticas públicas, vem se tornando um tema cada vez mais sensível para a Ciência Política contemporânea. No Brasil, o financiamento de campanhas eleitorais é um dos principais artifícios que o empresariado tem à disposição para manter sua influência na arena política. A presente dissertação busca analisar o comportamento parlamentar, no contexto pós-eleitoral, frente ao financiamento de campanhas de origem industrial. Mais que isso, pretende-se explicar, tendo em vista a dinamicidade do processo legislativo, quais são os fatores, para além do financiamento de campanhas, que podem, de forma agregada, influenciar na atuação do parlamentar nas proposições sinalizadas como prioritárias para a Confederação Nacional da Indústria (CNI), órgão máximo de representação industrial no Brasil, em suas Agendas Legislativas (ALIn), publicadas anualmente. Para tanto, optou-se pela utilização do método comparativo de análise, através da aplicação da Qualitative Comparative Analysis (QCA), uma vez que esta viabiliza a apreciação de fenômenos multicausais, como é o caso da relação entre dinheiro e comportamento parlamentar no Brasil.

Palavras-chave: Financiamento de campanhas; Comportamento parlamentar; Confederação Nacional da Indústria; Grupos de influência; Qualitative Comparative Analysis.

\begin{abstract}
The interference of private and corporative interests in governmental agendas, as well as the mechanisms used to influence public policies, is becoming an increasingly sensitive issue for Political Science in the contemporary world. In Brazil, campaign financing is one of the key tools that business group use to maintain its influence on political arena. This study analyzes the parliamentary behavior in the post-election context, across the campaign funds that originate from industry. Moreover, is intended to explain, given the dynamics of the legislative process, what are the factors, beyond the campaign financing, which in aggregate, influence the parliamentary action on proposals flagged as priorities for the Brazilian National Confederation of Industry (CNI), the highest representation of industrial sector in Brazil, in its Legislative Agenda (ALIn), published annually. Therefore, this study will use the comparative method, through the application of Qualitative Comparative Analysis (QCA), since it allows the appraisement of multicausal phenomena, such as the relationship between money and parliamentary behavior in Brazil.
\end{abstract}

Keywords: Campaign financing; Parliamentary behavior; Interest groups; Qualitative Comparative Analysis. 


\section{LISTA DE FIGURAS, QUADROS E TABELAS}

Figura 1 - Output gerado pelo crisp-set QCA

Quadro 1 - Métodos Quantitativos versus QCA .50

Quadro 2 - Frentes parlamentares do segmento industrial (54 legislatura) .57

Tabela 1 - Panorama Geral do Financiamento auferido pelos parlamentares envolvidos nas proposições prioritárias da CNI- Eleições de 2010 .23

Tabela 2 - Classificação das empresas doadoras quanto ao nível de investimento .24

Tabela 3 - Número de deputados por nível de investimento .26

Tabela 4 - Espécies de recursos, por total arrecadado e número de doações por recurso. .28

Tabela 5 - Montante do financiamento de campanhas - Governo versus Oposição .......32

Tabela 6 - Situação das proposições em outubro de 2015 .36

Tabela 7 - Posicionamento parlamentar convergente ou não com a CNI, de acordo com sua ideologia (pró ou contra o governo), na MP 595/2012 38

Tabela 8 - Posicionamento parlamentar convergente ou não com a CNI, de acordo com sua ideologia (pró ou contra o governo), na MP 627/2013

Tabela 9 - Posicionamento parlamentar convergente ou não com a CNI, de acordo com sua ideologia (pró ou contra o governo), no PL 037/2011 .42

Tabela 10 - Posicionamento parlamentar convergente ou não com a CNI, de acordo com sua ideologia (pró ou contra o governo), no PL 2126/2011 . .44

Tabela 11 - Posicionamento parlamentar convergente ou não com a CNI, de acordo com sua ideologia (pró ou contra o governo), no PLP 200/2012

Tabela 12 - Temas que figuram nas proposições das Pautas Mínimas (2011-2014)......59

Tabela 13 - Número de parlamentares financiados pela indústria que são atores-chave no processo legislativo

Tabela 14 - Montante do financiamento de origem industrial dos atores-chave, em ordem decrescente de valores.... .62

Tabela 15 - Categorias de comportamento .66 
LISTA DE ABREVIATURAS E SIGLAS

ALIn Agenda Legislativa da Indústria

ANM Agência Nacional de Mineração

CD Câmara dos Deputados

CEMPRE Cadastro Central de Empresas

CFEM Contribuição Financeira pela Exploração Mineral

CNI Confederação Nacional da Indústria

CNPJ Cadastro Nacional da Pessoa Jurídica

CNPM Conselho Nacional de Política Mineral

DEM Democratas

DIAP Departamento Intersindical de Assessoria Parlamentar

FGTS Fundo de Garantia por Tempo de Serviço

IBGE Instituto Brasileiro de Geografia e Estatística

MP Medida Provisória

PL Projeto de Lei

PLP Projeto de Lei Complementar

PMDB Partido do Movimento Democrático Brasileiro

PPS Partido Popular Socialista

PSB Partido Socialista Brasileiro

PSDB Partido da Social Democracia Brasileira

PT Partido dos Trabalhadores

PTB Partido Trabalhista Brasileiro

QCA Qualitative Comparative Analysis

RICD Regimento Interno da Câmara dos Deputados

RTT Regime Tributário de Transição

TSE Tribunal Superior Eleitoral 


\section{SUMÁRIO}

1 - INTRODUÇÃ

2 - DINHEIRO E COMPORTAMENTO PARLAMENTAR: UMA ANÁLISE DA

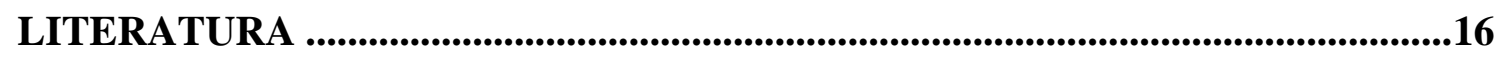

3 - PANORAMA DO FINANCIAMENTO DE CAMPANHAS NAS ELEIÇÕES

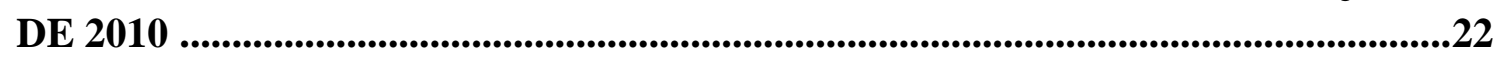

3.1 - Seleção das prestações de contas dos deputados apresentadas ao TSE ...............26

3.2 - Modalidades das arrecadações e repasses de campanha....................................28

3.3 - Analisando o contrafactual: o financiamento industrial sob a perspectiva

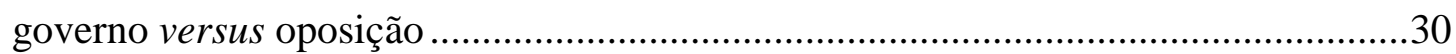

4 - A CNI ENQUANTO REPRESENTANTE DO EMPRESARIADO INDUSTRIAL NO BRASIL

4.1 - As proposições prioritárias das Pautas Mínimas da Confederação Nacional da

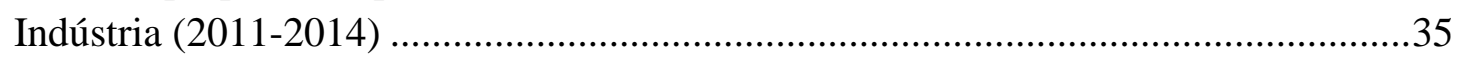

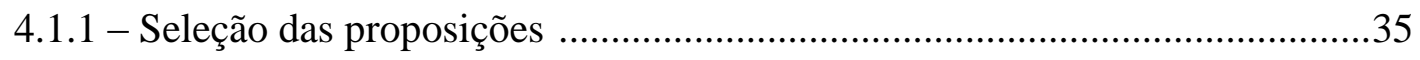

4.1.2 - Panorama das proposições selecionadas ....................................................36

5 - ANÁLISE DAS CATEGORIAS DE COMPORTAMENTO ..................................50

5.1 - A escolha do método: Qualitative Comparative Analysis (QCA) .......................50

5.2 - A Pauta Mínima da CNI em dados ...................................................................53

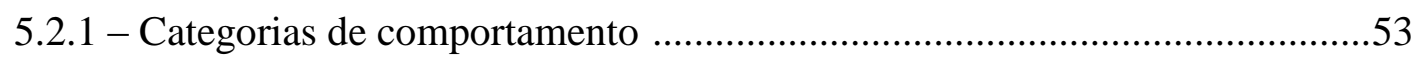

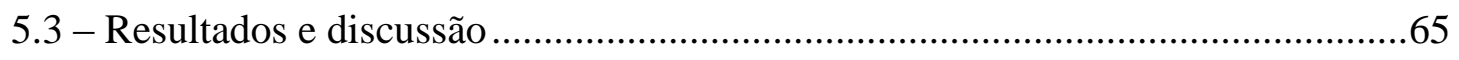

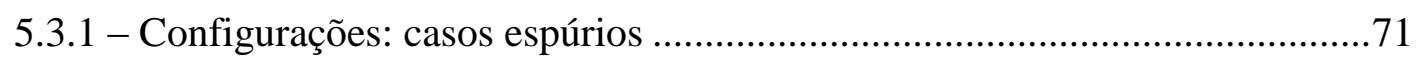

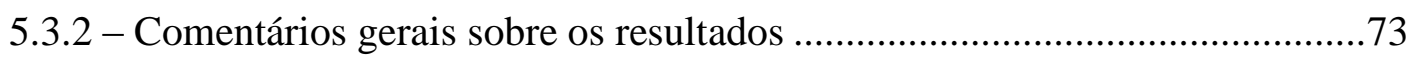

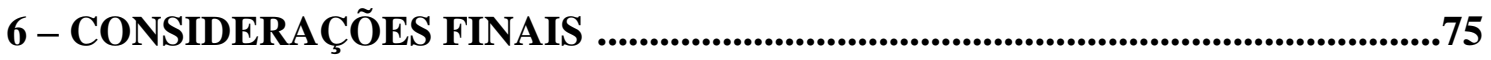

7 - REFERÊNCIAS BIBLIOGRÁFICAS .....................................................................78

8 - ANEXOS

8.1 - ANEXO A - Discurso do deputado Paes Landim (PTB/PI) ..............................84

8.2 - ANEXO B - Discurso do deputado Fábio Trad (PMDB/MS) ...........................87

8.3 - ANEXO C - Discurso do deputado Mauro Benevides (PMDB/CE) ..................89

8.4 - ANEXO D - Discurso do deputado Mauro Benevides (PMDB/CE) ..................91 


\section{1 - INTRODUÇÃO}

O debate sobre dinheiro e política, temática clássica nas democracias modernas, recorrentemente entra na pauta das propostas de reforma dos sistemas eleitorais ao redor do mundo. Mesmo nas democracias emergentes, o impacto do dinheiro na política, mais precisamente seu uso em campanhas eleitorais e as consequências deste, vem suscitando debates sobre como a relação dinheiro e política pode colocar em jogo o princípio democrático da igualdade entre os cidadãos, no tocante à sua participação na política. Tal prática acaba erodindo o princípio de one person, one vote: assim como existem disparidades de riqueza e renda na sociedade, os indivíduos e organizações que possuem mais dinheiro poderão contribuir mais com campanhas eleitorais, podendo vir a desequilibrar também a igualdade no processo de representação. O financiamento de campanhas é uma das principais ferramentas que o mundo dos negócios tem à disposição para manter sua influência sobre as decisões políticas.

Apesar de não ser um debate central na agenda de pesquisa, é inegável a influência dos grupos de interesse e pressão privados sobre as decisões públicas no Brasil. Como supracitado, a variável influência é comumente operacionalizada a partir da análise entre as contribuições de campanha, em um cenário pré-eleitoral, e o comportamento legislativo do parlamentar eleito agraciado pelo financiamento privado, no cenário pós-eleitoral. Nesse âmbito, esta pesquisa pretende aferir qual o efeito do financiamento de campanha da indústria sobre o comportamento dos parlamentares financiados por esse ramo: se eles votam de acordo com os interesses e a orientação da indústria. Desse modo, pretende-se suscitar novas perspectivas ao estudo da relação entre dinheiro e comportamento parlamentar no Brasil.

Nos Estados Unidos, o esforço normativo para regulamentar o custo das campanhas é datado do fim do século XIX. Existe legislação para fixar o teto para gastos em campanhas, por parte dos candidatos, a fim de tornar a disputa o quanto mais equânime possível. No Brasil, é facultado ao próprio candidato estabelecer seu teto de gastos previamente e informar ao Tribunal Superior Eleitoral (TSE), quando do registro de sua candidatura. Porém, este artifício é subvertido: uma vez ultrapassado o valor previamente estipulado, o candidato é multado. Para não correrem o risco de pagarem 
uma multa, equivalente a quatro vezes o valor ultrapassado ${ }^{1}$, os candidatos são orientados pela própria direção partidária a estipularem o valor bem acima do que pretendem gastar. Além de permitir que escapem da multa, esse tipo de atitude também demonstra algo que se torna bem claro ao observarmos as disputas eleitorais no Brasil: não existe um claro planejamento de gastos, o que também é indicador de que o dinheiro para o gasto da campanha não é fixo, podendo o candidato despender e receber qualquer monta a qualquer momento da campanha, tornando a disputa mais discrepante ainda, pois o candidato pode agir de acordo com as circunstâncias que ocorrerem durante a campanha. Quem tem mais dinheiro em caixa, consegue, por exemplo, utilizar de melhores estratégias de marketing eleitoral para suprimir seu opositor em uma reta final de campanha.

O marketing eleitoral é utilizado para persuadir o eleitor, fazendo com que ele compre a ideia de que um dado candidato é merecedor de seu voto. As decisões de voto, desse modo, perpassam pela avaliação dos candidatos, que está sujeita ao tipo de informação que vai chegar ao eleitor, o impacto visual que a campanha vai gerar no eleitor, bem como o alcance que a campanha proporcionará ao candidato. Para mobilizar todo esse aparato, é imprescindível que o candidato gaste dinheiro.

Apesar do esforço despendido pelos legisladores brasileiros, a Lei das Eleições (Lei $\mathrm{n}^{\circ}$ 9.504, de 30 de setembro de 1997), que coibiu as práticas de agraciar os eleitores com brindes ou benefícios pessoais em troca de voto, versa sobre restrições de cunho generalístico, não especificando as restrições, cabendo ao aplicador da lei a interpretação que lhe convier, principalmente nos casos de abuso de dinheiro em campanhas.

Apesar de robustos, são poucos e pontuais os estudos que tratam da temática da influência dos financiadores de campanha no Congresso Nacional brasileiro. Em grande parte, a preocupação primordial gravita em torno de um eixo central, que é aferir o impacto dos grupos de influência e pressão na atividade e no comportamento parlamentar. De acordo com Figueiredo Filho (2009), os trabalhos em âmbito de Brasil procuram responder a duas seguintes questões: como e em que medida as doações de

\footnotetext{
${ }^{1}$ Este valor teve como referência a Resolução 23.406, de 03/04/2014, que disciplinou a arrecadação e os gastos de campanha nas eleições de 2014.
} 
campanha influenciam as decisões dos congressistas; e como e em que medida as atividades dos grupos de influência afetam as ações dos parlamentares.

Configurando entre os campeões mundiais de campanhas caras (FLEISCHER, 2000; MAINWARING, 1999 apud SAMUELS, 2001), o processo eleitoral brasileiro é fortemente influenciado pelo poder do dinheiro. Por conta disso, muito se questiona sobre a verdadeira representatividade dos políticos brasileiros: se respondem ao eleitorado que lhes conferiu o mandato ou aos financiadores de campanha, o que acaba por gerar impasses metodológicos (WAWRO, 2001).

Apesar de a redemocratização brasileira ter ampliado a capacidade dos grupos de influência no processo de tomada de decisões públicas, ainda existem poucos estudos acadêmicos que tratam da temática. Os trabalhos de Mancuso (2004) e Santos (2014) são pioneiros no estudo da influência do empresariado nas tomadas de decisão do Congresso Nacional, seja via representação direta, por intermédio das frentes parlamentares, ou enquanto grupo de influência externo, organizado e coeso na persecução de seus interesses junto aos elaboradores de políticas públicas.

Assim como os candidatos precisam de dinheiro para mobilizar seus simpatizantes em época de eleições e, desta forma, conseguirem votos, os financiadores privados também possuem seus interesses junto aos parlamentares: seja para conseguirem acesso privilegiado ao parlamentar, seja para influenciarem votações no Congresso. Desse modo, cria-se uma espécie de dependência mútua entre financiador e financiado, semelhante a um "mercado de legislações" (CLAWSON, 2001).

Sob essa ótica, o financiamento de campanha é entendido como um mercado competitivo para obtenção de benefícios particularistas em políticas públicas. Porém, o processo de financiamento de campanha é muito mais flexível e incerto que uma transação de mercado. Além do recorrente problema da corrupção, a maior preocupação que essa dinâmica suscita é a criação de um complexo sistema de interações, que acaba por criar uma rede de obrigações entre financiador e financiado. 
Diante desse panorama, pretende-se estudar até que ponto o parlamentar ${ }^{2}$ é refém de seu financiador de campanha. Tendo como cenário o Congresso Nacional brasileiro, pretende-se aferir se o deputado que recebeu financiamento por parte da indústria tende a acompanhar ou não os interesses do empresariado na Câmara dos Deputados, traduzidos pelas proposições de interesse prioritário listadas na Agenda Legislativa (ALIn) da Confederação Nacional da Indústria (CNI), órgão máximo de representação industrial no país.

Para proceder à abordagem, serão utilizadas as proposições das Pautas Mínimas das ALIn de 2011 a 2014, período referente à 54a legislatura da Câmara dos Deputados, recém concluída. É na Pauta Mínima que se encontram listadas as proposições de interesse máximo do setor industrial. Das 57 proposições filtradas no referido período, somente oito se encaixaram no critério de análise da presente dissertação, estando elas distribuídas entre Projetos de Lei, Projetos de Lei Complementar e Medidas Provisórias. Como o propósito é aferir o comportamento do parlamentar, no âmbito de Câmara dos Deputados, em consonância às expectativas esperadas pela CNI em uma dada proposição, buscou-se selecionar as proposições cuja tramitação se encontrava em estágio avançado ou concluído, bem como as proposições cujo início da tramitação datava do período em análise, para que fosse possível estudar o comportamento dos deputados da $54^{\mathrm{a}}$ legislatura.

A seleção dos parlamentares se deu por conta de sua atuação nas proposições selecionadas, aferida por meio da análise das notas taquigráficas dos discursos proferidos em Plenário e pelo teor dos requerimentos apresentados (retirada de pauta; pedido de audiência pública; pedido de vista; adiamento de discussão e votação; inclusão na ordem do dia e pedido de urgência). A partir desta filtragem, foi possível contabilizar quais foram os parlamentares que agiram ou não em consonância com as orientações da CNI para uma determinada proposição.

Tendo em vista os vários fatores que podem influenciar o comportamento parlamentar no exercício de seu mandato, para além do financiamento de campanhas, optou-se pela utilização do método da Qualitative Comparative Analysis (QCA), que se baseia fundamentalmente na multicausalidade, priorizando um maior número de

\footnotetext{
2 Os termos "parlamentar" ou "parlamentares" fazem referência, ao longo desta dissertação, aos deputados federais em estudo. Excluiu-se da presente análise o Senado Federal, tendo em vista a dificuldade de acesso às informações desta Casa.
} 
explicações através da interação entre as variáveis em estudo, o que permite uma melhor visualização da realidade do recorte escolhido.

A presente dissertação está dividida em quatro capítulos. Ao primeiro, coube estabelecer um comparativo entre a realidade brasileira e norteamericana, à luz da literatura, no tocante à relação entre financiamento de campanha e comportamento parlamentar, uma vez que, nos Estados Unidos, a legislação não permite doações diretas aos candidatos em disputa, o que acaba viabilizando um controle sobre a origem do dinheiro que entra na disputa eleitoral, bem como o peso de sua influência no parlamentar agraciado. O segundo capítulo traça um panorama do financiamento de campanhas no período eleitoral em estudo, além de pormenorizar, em dados, as diversas vertentes da contribuição destinada aos candidatos eleitos que atuaram nas proposições prioritárias da indústria. O terceiro capítulo traz uma breve análise do papel da CNI enquanto representante do segmento empresarial no Brasil, principalmente em se tratando de atuação enquanto grupo de interesse organizado, culminando na elaboração da Agenda Legislativa da Indústria. Apresenta, ainda, o teor das proposições das Pautas Mínimas selecionadas para o presente estudo, bem como demais detalhes relevantes sobre as mesmas. O quarto capítulo, por sua vez, trata da análise metodológica escolhida para a realização da dissertação, justifica a escolha do método comparativo e traz os dados e resultados dos testes obtidos por meio do uso do software fs/QCA. Nas considerações finais, são apontados os principais achados empíricos, que dialogam com a pergunta norteadora desta dissertação: em meio aos diversos fatores que podem constranger um deputado, no exercício de seu mandato, qual o peso do dinheiro, via financiamento de campanhas, em seu comportamento? 


\section{2 - DINHEIRO E COMPORTAMENTO PARLAMENTAR: UMA ANÁLISE DA LITERATURA}

O que se observa na literatura é que não há um consenso quando se trata da análise da relação entre gastos de campanha e comportamento parlamentar. É indiscutível para grande parte da literatura que as campanhas eleitoras, em suas diferentes abordagens, influenciam nos resultados das urnas, principalmente quando o fator dinheiro entra em jogo. Embora haja discordância na literatura sobre o quanto ou quem os gastos de campanha influenciam, quase ninguém afirma que o dinheiro gasto por candidatos em suas campanhas não impactam os resultados eleitorais. As questões não esgotadas pela literatura, segundo Jacobson (2006), dizem respeito a como os gastos importam, o quanto os gastos são importantes e para quem o são.

Diferentemente do Brasil, nos Estados Unidos existe a cultura - e o incentivo, pela própria legislação do país, que imprime vantagens ao candidato que opta por este tipo de financiamento - ao fundraising individual, que se trata, grosso modo, de mobilizar o eleitorado, enquanto pessoa física, para angariar recursos de campanha. Sua existência silencia a influência política dos grupos de interesse (ANSOLABEHERE; DE FIGUEIREDO; SYNDER, 2003). Contrariamente, o que se observa nos recentes estudos de financiamento eleitoral dos eleitos para a Câmara dos Deputados do Brasil, como o de Machado (2013), é que, excetuando a contribuição dos familiares do concorrente e da doação pessoal, a contribuição oriunda de pessoas físicas é baixa, se comparada ao financiamento despendido pelas empresas, o que acaba fazendo com que o financiamento por parte das empresas seja o principal protagonista.

A lógica da legislação norteamericana que trata do financiamento de campanha é regular não só o volume de dinheiro recebido pelo candidato de pessoas físicas ou via $\mathrm{PACs}^{3}$, mas também estipular limites aos doadores: a legislação não permite que, da cota que um eleitor individual pode doar para campanha, que esta seja destinada integralmente a um candidato. Estes fatores acabam gerando certa equidade na disputa, inibindo que quem tenha endossado uma maior quantia de dinheiro em um candidato possa exercer sobre ele um maior poder de influência (SPECK, 2010).

\footnotetext{
${ }^{3}$ Da tradução do inglês: Comitês de Ação Política. Organizações criadas por grupos de interesses para financiar campanhas eleitorais nos Estados Unidos, uma vez que a lei americana proíbe doação direta de uma pessoa jurídica para um candidato ou partido.
} 
A influência dos colaboradores de campanha sobre os representantes ganha várias interpretações na literatura. Uma vertente mais moderada defende que as empresas garantem, com o financiamento, acesso aos políticos beneficiados, sendo que o acesso, por sua vez, é a garantia de influência privilegiada daquele grupo sobre o processo decisório. Outra vertente interpreta o financiamento por parte das empresas como uma garantia de acesso à administração pública, privilegiando a empresa financiadora em processos de licitação, obras ou acesso a crédito de bancos públicos (CLAWSON, 2001; LANGBEIN, 1986; SPECK, 2010).

Uma preocupação que surge quando da avaliação de sistemas de financiamento em diferentes países, segundo Speck (2010), é que o dinheiro na política pode levar a três dilemas: minar a igualdade política do cidadão pela desigualdade no financiamento; a desigualdade no financiamento causar desequilíbrio na disputa; e haver subversão da integridade do candidato que recebe uma alta monta de dinheiro por parte de empresas. A preocupação, desse modo, é como lidar com os atores que podem desequilibrar o processo eleitoral.

Por conta disso, Jacobson (2006) alerta para a necessidade de se diferenciar, em uma análise, o que são effects of campaigning (efeito da mobilização das campanhas eleitorais) e o que são os effects of campaign spending (os efeitos dos gastos de campanha). De acordo com a lógica eleitoral do Brasil, o segundo efeito viabiliza o primeiro. Uma vez que o candidato consiga realizar um campaigning de peso, viabilizado pelo campaign spending, ele será capaz de se destacar dos demais, alcançar um maior eleitorado com as suas mídias, contratar staff mais bem preparado e, assim, aumentar as suas chances de ter sucesso eleitoral.

De acordo com o que aponta a literatura, nos Estados Unidos ocorre o inverso: o dinheiro, bem como a forma isonômica com que o financiamento e os gastos de campanha são regulados, é aplicado para fazer com que os candidatos disputem de forma equânime, uma vez que, como já citado, existe um teto para os gastos de campanha (SPECK, 2010). A expectativa de votos e a chance de sucesso eleitoral dos candidatos à reeleição declinam na medida em que o gasto de campanha cresce (JACOBSON, 2006; SPECK, 2010).

O debate sobre os diferentes impactos do financiamento de campanha dado aos incumbents (candidatos detentores de cargos) e aos challengers (candidatos que não 
possuem cargo) nos outputs eleitorais é recorrente na literatura norteamericana. Sob essa ótica, é possível pautar outra análise que circunda o tema: se os candidatos são eleitos por serem bem financiados ou se são bem financiados por serem competitivos.

Via de regra, no caso americano, os candidatos que já estão no cargo, ou seja, candidatos à reeleição, tendem a sair na frente na campanha e ter menos problema com financiamento, tendo em vista que seu gasto tende a ser menor, por já ser figura conhecida do eleitorado e gozar de certa proteção do sistema eleitoral, como no caso do Brasil (SAMUELS, 2001). Seu gasto com campanha cresce, no entanto, com a magnitude da ameaça eleitoral que enfrentam: quanto maior o problema que enfrentam, mais tendem a gastar. $\mathrm{O}$ oposto ocorre com os challengers: por terem menos visibilidade - e provavelmente menos popularidade, apesar de serem nomes competitivos - que os incumbents, necessitam maior soma de dinheiro para se tornarem conhecidos pelo eleitorado e, assim, enfrentarem a máquina da reeleição. Neste caso, o dinheiro tem relação direta com o resultado eleitoral: os gastos de campanha são endogenamente determinados pelas expectativas sobre os resultados das eleições (JACOBSON, 2006).

Outra questão que influencia a relação do candidato com o dinheiro em campanha, além da questão incumbents versus challengers, é a que trata do perfil dos financiadores de campanha. Assim como os candidatos, os financiadores agem estrategicamente: na lógica norteamericana, raramente apostarão em um candidato que não tem apelo. Quanto melhores forem as perspectivas de vitória de um candidato, mais os financiadores estarão dispostos a investir em sua campanha, diferentemente do que ocorre no Brasil, onde os financiadores preferem pulverizar o financiamento em um maior número de candidatos possível, agindo como em um mercado de risco, investindo pouco em uma ampla gama de candidatos, aceitando perder alguns investimentos, na certeza do retorno em outros (ANSOLABEHERE; FIGUEIREDO; SYNDER, 2003). Jacobson (2006) sintetiza essa análise, afirmando que o dinheiro pode ser um diferencial para ajudar a levantar votos, mas a expectativa de vitória de um candidato é um forte fator para que ele atraia financiadores.

Uma das possíveis motivações para que o empresariado contribua financeiramente com campanhas eleitorais é a possibilidade de influenciar a votação dos parlamentares em relação aos temas afetos à indústria. A possibilidade de ter acesso 
privilegiado ao parlamentar, viabilizando, assim, influência direta em políticas públicas ou privilégios em ações do governo é outra possível motivação para que grupos de interesse contribuam com as campanhas eleitorais (LANGBEIN, 1986). Ainda segundo a autora, as contribuições de campanha, em si, possuem pouco significado para um parlamentar, por não carregarem uma contrapartida explícita. Apenas o acesso, ou alguma outra forma de comunicação direta ou indireta entre o financiador e o financiado, pode traduzir dinheiro em influência.

A literatura brasileira, no entanto, mostra que a lógica de competição no Brasil, onde o sistema eleitoral influencia campanhas de cunho personalístico e disputas intrapartidárias entre candidatos, é pautada pelo esforço dos candidatos em se destacarem mais que seus concorrentes, se envolvendo em uma ampla variedade de atividades de campanha de alto custo (SAMUELS, 2001), fazendo com que o candidato precise de um grande volume de dinheiro para tal, viabilizado pelos financiadores, oriundo, em sua maioria, da contribuição dos grupos de interesses (MACHADO, 2013; SANTOS, 2012).

Os trabalhos de Wagner Mancuso são referência quando se trata da análise da influência dos grandes financiadores privados na produção legislativa. Corroborando a ideia da pesquisa e as informações do banco de dados elaborado para classificar a área de atuação dos principais financiadores, Mancuso (2004) também identifica a relevância dos atores que Santos (2012) denominou big donors: a indústria. O autor ressalta a importância de se estudar a ação do empresariado, enquanto sociedade civil, em uma arena de tomada de decisões de alcance público, ou seja, o Congresso. Além de tratar da ação, Mancuso identifica quais os meios e instrumentos utilizados pela indústria para a consecução de seus interesses.

Para a análise da atuação dos grupos de interesse e do engajamento parlamentar em uma determinada causa, por conta de sua intensa atuação em uma dada proposição, é interessante observar três questões basilares, propostas por Coutinho (1995), apud Machado (2013): como se representa tais interesses; de quem, de fato, são esses interesses e quais são as motivações para defender/representar interesses.

O livro de Thomaz (2012) aproxima-se da proposta desta pesquisa e também do que delineara Mancuso (2004). A autora analisa as estratégias de grupo de interesse específico, no caso, o da indústria do etanol, na consecução de seus interesses junto ao 
governo norteamericano. Thomaz identifica que, para tal, primeiramente os atores buscam mobilizar a opinião pública, a fim de obter apoio desta para que possa agir na esfera política. Após justificar sua ação socialmente, os industriais do etanol atuam no pré e no pós-eleitoral: doam dinheiro para as campanhas dos potenciais candidatos e, ainda por cima, fazem todo o trabalho de convencer os eleitores a votarem nestes, com o argumento de que se trata de uma questão de interesse social e coletivo. Consecutivamente, atuam direta e incisivamente na defesa de sua agenda junto aos políticos na arena de produção legislativa, buscando influenciar as decisões dos parlamentares, a fim de terem seus interesses alcançados.

Diferentemente do contexto analisado por Thomaz, a questão da mobilização da opinião pública em torno de um tema, em se tratando de Brasil, portanto, pode gerar ruído na relação direta entre financiador e parlamentar, pois a pressão passa a ser não só do grupo de interesse sobre o parlamentar, mas também da opinião pública (CLAWSON, 2010), o que pode vir a fazê-lo mudar seu posicionamento original.

Um dos grandes problemas dos estudos legislativos, enquanto grande área de conhecimento, é tratar as suas principais abordagens como fenômenos monodimensionais, baseando-se, principalmente, em abordagens "distributivistas", que elenca o sistema eleitoral como principal variável explicativa; ou em abordagens “partidárias", para explicar o processo legislativo (PERES; CARVALHO, 2012). Esse insulamento dos fenômenos, tendo em vista a realidade dinâmica da atividade legislativa, acaba por prejudicar a análise, uma vez que os resultados que se obtém, ao se proceder a uma abordagem monodimensional, podem não necessariamente explicar, de forma adequada, a realidade do objeto de estudo.

Levando em conta a dinamicidade da Câmara dos Deputados e os diversos constrangimentos a que os parlamentares estão diariamente expostos, no tocante à atividade parlamentar, é oportuno colocar em prova os diferentes fatores que podem influenciar o comportamento parlamentar, no exercício de seu mandato. Para tanto, para além da abordagem do financiamento de campanhas, é imprescindível que se elenque as demais variáveis que, em consonância com a principal, possam explicar quais os fatores que podem incidir no comportamento do parlamentar em uma determinada proposição.

Trabalhos como o de Mancuso e Speck (2015) ressaltam a importância de se analisar os condicionantes do financiamento de campanhas sob a influência de 
diferentes fatores, ou seja, múltiplas variáveis. Ao tratar das diversas variáveis que podem influenciar o financiamento eleitoral empresarial no Brasil, em um contexto préeleitoral, os autores defendem que, como não é possível prever o que determina as escolhas das empresas ao financiar um determinado parlamentar, muito menos o que esperam com essa ação, cabe ao pesquisador inferir quais as variáveis que podem influenciar a análise.

De acordo com os padrões observados no financiamento de campanhas, os autores levantaram variáveis de natureza política e eleitoral. Assim como no trabalho supracitado, na presente dissertação, a escolha das variáveis se deu a partir da observação dos perfis dos parlamentares e, consequentemente, da sua ação parlamentar, levando em conta os múltiplos fatores que poderiam influenciar no seu comportamento em uma dada proposição. Também se levou em conta os possíveis ruídos que poderiam surgir na análise. Para tanto, procedeu-se à análise do contrafactual, levando em conta o fato de que o parlamentar pode sofrer constrangimento de um dos principais agenda setters do Legislativo: o Poder Executivo.

Tratando o fenômeno sob a ótica da multicausalidade, é possível, portanto, aproximar o objeto de estudo à realidade a que ele se insere, fazendo com que os resultados esperados apresentem uma resposta mais fidedigna à pergunta norteadora da presente dissertação: o que o dinheiro, oriundo do financiamento de campanhas, é capaz de comprar? O uso da QCA, portanto, indica uma escolha metodológica que se baseia fundamentalmente na multicausalidade, onde um determinado arranjo configuracional entre diferentes variáveis podem explicar o fenômeno do comportamento parlamentar sob um viés mais realístico.

Espera-se, com a análise, aprender quais são os fatores que, aliados ao financiamento de campanhas, podem influenciar o comportamento dos deputados quando do posicionamento nas proposições prioritárias para a CNI, sem deixar de lado, portanto, a importância e o peso do fator financeiro nas escolhas individuais dos parlamentares agraciados pelas contribuições de campanha de origem empresarial. 


\section{3 - PANORAMA DO FINANCIAMENTO DE CAMPANHAS NAS ELEIÇÕES} DE 2010

O pleito eleitoral de 2010, segundo os dados disponibilizados pelo Tribunal Superior Eleitoral (TSE), mobilizou um total de R 4,7 bilhões de reais, número referente ao total geral arrecadado pelos candidatos em disputa, em todos os níveis (MACHADO, 2013). Esse montante foi calculado com base nas prestações de contas finais ${ }^{4}$ apresentadas pelos candidatos ao TSE, obrigatoriedade disciplinada pela Lei $\mathrm{n}^{\circ}$ 9.504, de 30 de setembro de 1997 (Lei das Eleições), em seu artigo 28, §4º.

Diferentemente de países como os Estados Unidos, onde a arrecadação é unificada, no Brasil, o repasse do dinheiro, fruto do financiamento eleitoral, é feito diretamente pelo financiador ao partido ou candidato, cabendo a estes prestar contas ao TSE de tudo o que foi arrecadado e gasto. O TSE também solicita aos prestadores de serviços, como empresas de publicidade e gráficas, informações sobre os contratos firmados com os partidos ou candidatos. Porém, essa informação, diferentemente das prestações de contas, não são disponibilizadas publicamente (MANCUSO; SPECK, 2011).

De acordo com a legislação eleitoral suprarreferenciada, cabe aos candidatos prestarem contas individualmente e via comitê financeiro, a quem cabe cuidar de toda a logística das arrecadações e gastos. No caso em estudo, onde o enfoque é dado aos parlamentares que aparecem enquanto atores nas proposições elencadas como prioridade máxima pela Confederação Nacional da Indústria $(\mathrm{CNI})$, nas quatro edições das Pautas Mínimas em estudo, será analisado somente o financiamento fruto de pessoas jurídicas, ou seja, de origem empresarial ou industrial. Porém, para que se tenha noção do montante mobilizado por essa modalidade de financiamento, em um primeiro momento, proceder-se-á à sua análise dentro do universo do financiamento despendido aos 239 parlamentares eleitos que atuaram nas proposições em estudo.

Individualmente, os 239 parlamentares arrecadaram, em receita, um total de $\mathrm{R} \$$ 248.955.607,80 milhões, o que equivale a aproximadamente 5,3\% do total geral mobilizado pelo pleito. Este valor é equivalente às doações oriundas de pessoas físicas;

\footnotetext{
${ }^{4}$ Ao longo do pleito, os candidatos devem apresentar ao TSE, eletronicamente, duas prestações de contas parciais de receitas e despesas, além da prestação de contas final, estando sob pena de não terem suas contas finais aprovadas, caso não apresentem a $1^{\mathrm{a}}$ e a $2^{\mathrm{a}}$ parciais dentro do prazo estipulado pelo tribunal ou deixem de apresentá-las.
} 
pessoas jurídicas (empresas); candidatos a cargos políticos eletivos, como deputados estaduais, senadores e governadores; do próprio candidato, estando também inclusos o repasse oriundo do comitê financeiro (único, estadual ou distrital) e dos diretórios de partido (estadual, distrital ou nacional), na forma como disciplina a Lei das Eleições. A Tabela 1 elenca os respectivos valores despendidos pelos financiadores, dentro das categorias mencionadas.

Tabela 1 - Panorama Geral do Financiamento auferido pelos parlamentares envolvidos nas proposições prioritárias da CNI- Eleições de 2010

\begin{tabular}{|c|c|c|}
\hline Tipo de doador & Volume das doações & Porcentagem \\
\hline Candidato a cargo político eletivo & $\mathrm{R} \$ 5.680 .189,62$ & $2,28 \%$ \\
\hline Comitê financeiro & $\mathrm{R} \$ 28.387 .457,81$ & $11,40 \%$ \\
\hline Diretório de partido & $\mathrm{R} \$ 46.692 .193,93$ & $18,76 \%$ \\
\hline $\begin{array}{c}\text { Doação de pessoa física e doação } \\
\text { do próprio candidato }\end{array}$ & $\mathrm{R} \$ 46.570 .216,50$ & $18,71 \%$ \\
\hline Empresas & $\mathrm{R} \$ 121.625 .549,92$ & $48,85 \%$ \\
\hline TOTAL & $\mathbf{R} \$ \mathbf{2 4 8 . 9 5 5 . 6 0 7 , 8 0}$ & $\mathbf{1 0 0 \%}$ \\
\hline
\end{tabular}

Fonte: Elaboração própria, com base em dados extraídos do sítio do TSE.

Segundo a tabela acima, é possível observar que as doações oriundas de pessoas físicas ou dos próprios candidatos, enquanto pessoas físicas, representam $18,71 \%$ do total geral auferido pelos parlamentares envolvidos nas proposições. Tal fato corrobora o que já fora apontado pela teoria, que afirma a falta de cultura do brasileiro em contribuir pessoalmente com campanhas eleitorais, ao contrário de países como os Estados Unidos, a título de exemplo, onde a mobilização em torno do eleitorado para que este participe, inclusive enquanto financiador da campanha do seu candidato de preferência, embora em pequenas montas, tem gerado retornos positivos para os candidatos (ANSOLABEHERE; FIGUEIREDO; SYNDER, 2003).

Embora seja baixo o volume mobilizado pelas pessoas físicas, esse valor ainda é maior que o montante mobilizado pelos comitês financeiros $(11,4 \%)$ e o financiamento oriundo dos candidatos a cargos políticos eletivos $(2,28 \%)$, podendo ser candidatos deputados estaduais, senadores ou governadores do estado de origem de um 
referido candidato a deputado federal. Não obstante, o montante mais alto cabe às doações de origem empresarial, somando o total de $\mathrm{R} \$ 121.625 .549,92$ milhões, quase $50 \%$ do total geral das receitas declaradas pelos deputados em estudo.

De acordo com o Cadastro Central de Empresas do Instituto Brasileiro de Geografia e Estatística (Cempre), existiam 5,1 milhões de empresas economicamente ativas no Brasil em 2010 (MACHADO, 2013). Destas, 2.593 doaram para os 239 deputados envolvidos com as proposições da CNI, número que representa $0,05 \%$ do total de empresas ativas em 2010 e 12,4\% do total das empresas (20.448) que participaram do pleito de 2010 como financiadoras, segundo o TSE. Embora ambos os percentuais sejam baixos, não deixam de ser representativos, uma vez que endossam a teoria, no sentido de corroborar que, apesar do financiamento de campanhas fazer parte de um mercado bastante capitalizado, é dominado por poucos atores (SAMUELS, 2006), que pulverizam seu investimento, em forma de doação eleitoral, em vários e diferentes candidatos, para que, assim, como em um mercado de risco, não tenha o perigo de sair como um total perdedor.

Tabela 2 - Classificação das empresas doadoras quanto ao nível de investimento

\begin{tabular}{|l|c|c|}
\hline \multicolumn{1}{|c|}{ Nível de investimento } & Volume das doações & Quantidade de doadores \\
\hline 1 - Até R\$ 5 mil & $\mathrm{R} \$ 4.965 .860,46$ & 1336 \\
\hline 2 - Entre R \$ 5 e 10 mil & $\mathrm{R} \$ 7.196 .113,12$ & 524 \\
\hline 3 - Entre R \$ 10 e 50 mil & $\mathrm{R} \$ 50.132 .186,83$ & 905 \\
\hline 4 - Entre R \$ 50 e 100 mil & $\mathrm{R} \$ 30.925 .416,51$ & 206 \\
\hline 5 - Entre R\$ 100 e 500 mil & $\mathrm{R} \$ 28.405 .973,00$ & 91 \\
\hline Total geral & $\mathbf{R} \$ \mathbf{1 2 1 . 6 2 5 . 5 4 9 , 9 2}$ & $\mathbf{3 0 6 2}$ \\
\hline
\end{tabular}

Fonte: Elaboração própria, com adaptações do modelo intervalar utilizado por Speck (2012).

A Tabela 2 acima classifica as doações por níveis de investimento. É possível notar, no entanto, que os intervalos não apresentam um quantitativo exato entre si e que o total de empresas doadoras é maior à supracitada, de 2.593. Isso ocorreu justamente pelo fato de muitas empresas doarem diferentes quantias a um mesmo candidato ou 
aparecerem na prestação de contas de vários destes, fazendo com que um mesmo $\mathrm{CNPJ}^{5}$ aparecesse mais de uma vez nos intervalos da tabela.

Ao analisar a tabela, é possível notar que, proporcionalmente, o nível 1 é o que possui maior quantidade de empresas financiadoras. Porém, é no nível 3, das empresas que doaram entre $\mathrm{R} \$ 10$ mil e $\mathrm{R} \$ 50$ mil reais, que está o maior volume de doações. De fato, ao coletar os dados, notou-se que um maior número de empresas doou a quantia de exatos R $\$ 10$ mil reais, enquanto no nível 1, o mesmo ocorreu com o valor de $\mathrm{R} \$ 1$ mil reais, mas não com a mesma proporção dos que optaram por doar R $\$ 10$ mil reais, no nível 3. Observa-se que, de fato, poucas empresas doam altas somas, como no caso do nível 5: apenas três doaram acima de $\mathrm{R} \$ 300$ mil reais. Aqui, mantém-se a lógica da pulverização do investimento, destinando quantias menores a um maior número de candidatos, como nota-se no nível 1. Embora os intervalos de valores não sejam exatos ${ }^{6}$, se se estipular um intervalo de 5 mil reais em cada nível, ainda assim o nível 1 consegue vencer o nível 3 no quantitativo de empresas investidoras. Porém, a mediana do investimento se mantém no nível 3, enquanto o menor quantitativo é resguardado ao nível de investimento com os maiores valores (nível 5).

Pela Tabela 2, nota-se que o quantitativo geral de deputados por nível é superior ao total real de deputados da Frente Parlamentar da Indústria. Isso se deve pelo fato de que os candidatos, individualmente, receberam diferentes valores de financiamento, o que faz com que seus nomes apareçam mais de uma vez nos diferentes níveis, justificando o total geral em dissonância com o número total de deputados da Frente.

Poucos também são os deputados que receberam investimento do nível 5, o maior nível, ficando o maior número justamente no nível 1, que é, proporcionalmente, o nível com os menores valores de doações individuais e, igualmente, o menor em volume total. O segundo maior valor, discretamente superior ao nível 1, corresponde à mediana de valores doados, ou seja, o nível 3, correspondente ao montante de R $\$ 10$ mil reais, número que aparece mais vezes nas prestações de contas. Interessante observar que a lógica dos valores inversamente proporcionais se repete tanto na Tabela 2 (nível de

\footnotetext{
${ }^{5}$ Acrônimo de Cadastro Nacional da Pessoa Jurídica.

${ }^{6}$ Como mencionado, os intervalos entre os valores não possuem uma sequência entre si, como no modelo de Speck (2012). Desse modo, se se levar em conta um intervalo entre 5 e 5 mil reais em cada nível, o nível 1 consegue vencer o nível 3 no quantitativo de empresas investidoras.
} 
investimento versus quantidade de empresas investidoras) quanto na Tabela 3 (nível de investimento versus quantidade de deputados agraciados): quanto menor o nível de investimento, maiores são as quantidades de elementos envolvidos, valendo também a premissa inversa.

Tabela 3 - Número de deputados por nível de investimento

\begin{tabular}{|l|c|c|}
\hline \multicolumn{1}{|c|}{ Nível de investimento } & Volume das doações & Quantidade de deputados \\
\hline 1 - Até R\$ 5 mil & $\mathrm{R} \$ 4.965 .860,46$ & 199 \\
\hline 2 - Entre R\$ 5 e 10 mil & $\mathrm{R} \$ 7.196 .113,12$ & 154 \\
\hline 3 - Entre R\$ 10 e 50 mil & $\mathrm{R} \$ 50.132 .186,83$ & 102 \\
\hline 4 - Entre R\$ 50 e 100 mil & $\mathrm{R} \$ 30.925 .416,51$ & 62 \\
\hline 5 - Entre R\$ 100 e 500 mil & $\mathrm{R} \$ 28.405 .973,00$ & $\mathbf{7 0 8}$ \\
\hline Total geral & $\mathbf{R} \$ \mathbf{1 2 1 . 6 2 5 . 5 4 9 , 9 2}$ & \\
\hline
\end{tabular}

Fonte: Elaboração própria.

\section{1 - Seleção das prestações de contas dos deputados apresentadas ao TSE}

As informações atinentes ao financiamento individual dos parlamentares eleitos da Frente Parlamentar da Indústria foram extraídas do sítio virtual do $\mathrm{TSE}^{7}$, de todos os candidatos que apresentaram a prestação de contas final. Como a busca é feita manualmente, bem como a compilação dos dados em um banco único, foi possível notar algumas peculiaridades em algumas prestações de contas.

O deputado João Lyra (PSL/AL) foi o único que recebeu financiamento oriundo exclusivamente do comitê financeiro, declarando o valor de $\mathrm{R} \$ 300,00$ para realizar uma campanha em nível de estado, que é a campanha para deputado federal. Já as contas do deputado Domingos Sávio (PSDB/MG) não constam no sistema de prestação de contas do TSE como entregues, assim como ocorreu com o deputado

\footnotetext{
${ }^{7}$ Link direto para a página referente às prestações de contas individuais, referentes ao pleito de 2010: http://spce2010.tse.jus.br/spceweb.consulta.prestacaoconta2010/pesquisaCandidato.jsp. A busca é realizada ao informar a unidade da federação e o cargo do concorrente. Os resultados reportados aparecem em bloco, ou seja, de todos os candidatos que apresentaram a referida prestação de contas para aquela unidade da federação e para o cargo selecionado.
} 
Gabriel Guimarães (PT/MG). Isso é curioso, pois se o candidato não apresenta as contas ao TSE no prazo estipulado pelo Tribunal, cabe à justiça aplicar as sanções cabíveis, que é a não diplomação do candidato eleito. Porém, ambos foram diplomados e exerceram o mandato.

Apesar de curiosos, os dois casos supracitados possivelmente podem ser enquadrados na situação dos gastos pessoais dos eleitores em favor dos candidatos, que é diferente da doação direta de recursos aos mesmos, de acordo com a Cartilha Sobre a Prestação de Contas das Eleições $2014^{8}$ (TRIBUNAL SUPERIOR ELEITORAL, 2014):

O eleitor pode realizar gastos pessoais em favor de candidatos, desde que não ultrapassem o valor de $\mathrm{R} \$ 1.064,10$, que a emissão da nota fiscal seja realizada em seu nome e que os bens ou serviços adquiridos não sejam entregues aos candidatos. Nessa hipótese, não estão sujeitos a registro na prestação de contas, desde que não sejam reembolsados.

Existem, portanto, casos previstos pela Justiça Eleitoral, de gastos não passíveis de contabilização na prestação de contas individuais dos candidatos, como o referenciado acima. Não é possível, portanto, aferir se este foi o caso dos candidatos supracitados, pois foge ao propósito desta dissertação.

Alguns candidatos chamaram a atenção pelo baixo volume de doadores, como no caso do deputado Reguffe (PDT/DF), que, além das doações de quatro pessoas físicas, que somam o montante de $\mathrm{R} \$ 43.800,00$, obteve o repasse do diretório nacional do seu partido, no valor de $\mathrm{R} \$ 100$ mil reais. Apesar de poucos doadores declarados, nenhum destes de origem industrial, o valor mobilizado foi significativamente alto, ao contrário do deputado Edson Silva (PROS/CE) que, embora também tenha apresentado em sua prestação de contas a doação de uma única pessoa física, além de suas doações pessoais e dos repasses do comitê financeiro, mobilizou um montante relativamente baixo, em relação aos demais candidatos, $\mathrm{R} \$ 43$ mil reais. Em suas contas, também não constam doações de origem empresarial.

\footnotetext{
${ }^{8}$ Embora a cartilha faça referência às eleições de 2014, a relevância da informação é para subsidiar o argumento de que existe a possibilidade de o candidato receber recursos de campanha, via gastos pessoas de pessoas físicas, que não são contabilizáveis na prestação de contas.
} 
Outros chamaram a atenção pelo alto volume de doadores, como no caso do deputado Renzo Braz (PP/MG). O deputado, que é de origem industrial, foi da base de apoio ao governo na Câmara na 54 $4^{\mathrm{a}}$ legislatura e é pertencente à Frente Parlamentar da Indústria ${ }^{9}$, auferiu um total de mais de $\mathrm{R} \$ 3,6$ milhões em receitas, número que representa o total de 5.184 doadores declarados. Destes, $\mathrm{R} \$ 2.697 .399,38$ milhões são referentes às doações de pessoas jurídicas, que apesar de ocuparem duzentas células na planilha do banco de dados, fazem referência a apenas dezessete empresas, que doaram quantias diferentes em uma quantidade maior de vezes ao candidato.

\section{2 - Modalidades das arrecadações e repasses de campanha}

De acordo com o manual técnico de arrecadação e aplicação de recursos e de prestação de contas das eleições de 2010 (TRIBUNAL SUPERIOR ELEITORAL, 2010), referência para o pleito em estudo, são considerados recursos de campanha, ainda que fornecidos pelo próprio candidato: cheque, transferência bancária, boleto de cobrança com registro; cartão de crédito ou cartão de débito; título de crédito; bens e serviços estimáveis em dinheiro; e depósitos em espécie devidamente identificados.

Nas prestações de contas dos 239 deputados em estudo, observou-se a seguinte distribuição de recursos:

Tabela 4 - Espécies de recursos, por total arrecadado e número de doações por recurso

\begin{tabular}{|c|c|c|}
\hline Espécie de recurso & Valor por espécie & $\begin{array}{c}\text { Número de doações por } \\
\text { espécie }\end{array}$ \\
\hline Boleto de cobrança & $\mathrm{R} \$ 200,00$ & 2 \\
\hline Cartão de crédito & $\mathrm{R} \$ 33.422,75$ & 80 \\
\hline Cheque & $\mathrm{R} \$ 74.762 .858,04$ & 5730 \\
\hline Depósito em espécie & $\mathrm{R} \$ 19.960 .854,50$ & 4059 \\
\hline Estimado & $\mathrm{R} \$ 21.153 .303,77$ & 17045 \\
\hline
\end{tabular}

\footnotetext{
${ }^{9}$ A expressão será utilizada no lugar da expressão original, "Frente Parlamentar em Defesa da Indústria Nacional", visando maior didaticidade e melhor compreensão por parte do leitor.
} 


\begin{tabular}{|c|c|c|}
\hline Não informado & $\mathrm{R} \$ 31.540,45$ & 42 \\
\hline Outros títulos de crédito & $\mathrm{R} \$ 20.400,00$ & 5 \\
\hline Transferência eletrônica & $\mathrm{R} \$ 132.993 .028,27$ & 3398 \\
\hline
\end{tabular}

Fonte: Elaboração própria.

Os "recursos estimados", ou recursos estimáveis em dinheiro, que aparecem em maior número de doações na Tabela 4, embora não seja o maior número em valor de doações, são "recursos recebidos diretamente, pelos candidatos e partidos, de bens ou serviços prestados, mensuráveis em dinheiro, mas que, por sua natureza, não transitam em conta bancária e não geram desembolso financeiro para candidatos e comitês financeiros. Podem ser provenientes de doações ou do patrimônio particular do próprio candidato" ${ }^{\prime 10}$. Em outras palavras, são os serviços gratuitos ou bens emprestados para a campanha, que devem ser contabilizados em dinheiro para entrar na prestação de contas. Um muro cedido pelo eleitor para fins propagandísticos, o carro utilizado na campanha, os santinhos, gravações e demais materiais propagandas que o partido ceder ao candidato são exemplos de recursos estimados.

Principalmente em campanhas realizadas em pequenas municipalidades, os recursos estimáveis são muito utilizados, tendo em vista que, por vezes, o acesso ao Horário Gratuito de Propaganda Eleitoral (HGPE) não é disponível em determinadas regiões. De igual modo, o acesso às novas mídias e redes sociais, linha de frente das campanhas eleitorais desde 2010, não é disseminado, cabendo ao candidato recorrer aos antigos recursos, tais como investir em panfletagem, propaganda em muros e em carros de som volantes, o que justificaria o alto nível das doações desta espécie de recurso.

Já a espécie "transferência eletrônica", ou transferência eletrônica de depósitos, foi a que somou um maior montante de arrecadações, em valores, muito acima da modalidade "depósito em espécie", o que pode vir a ser um bom indicativo, já que este, diferentemente dos demais recursos, possibilita o rastreio do seu remetente, uma vez que a transferência é realizada entre contas bancárias cuja titularidade do emissor é reconhecida.

Apesar da categorização dos recursos auferidos pelos candidatos, bem como a prestação de contas dos candidatos, a obrigatoriedade exigida pela Lei das Eleições, por

\footnotetext{
${ }^{10}$ Fonte: Sítio virtual do Tribunal Regional Eleitoral de Santa Catarina (TRE/SC). Acesso em 16/12/2015.
} 
conta de sua discricionariedade, não inibe a prática da utilização de recursos extraordinários não contabilizados em campanhas, conhecido também como "Caixa 2". A única exigência é que o candidato apresente as contas, conforme pauta a legislação, em suas diversas peculiaridades. Uma vez aprovadas as contas, o candidato está apto a ser diplomado. Os recursos extraordinários fogem ao controle das prestações de contas e da Justiça Eleitoral, que conta com o apoio da comunidade para rastrear os casos, por meio de denúncias oferecidas pelos eleitores ao Ministério Público.

\section{3 - Analisando o contrafactual: o financiamento industrial sob a perspectiva governo versus oposição}

Como já afirmado alhures, os financiadores de origem empresarial agem, em relação às campanhas, como se estivessem em seu habitat, ou seja, tratam o financiamento sob a mesma lógica de um mercado acionário, estando sujeitos a perdas e ganhos (MACHADO, 2013). Por conta disso, optam por pulverizar o dinheiro destinado às doações de campanha não em somente um candidato, mas em vários, sem distinção partidária, inclusive, fato que diminui as chances de o empresariado não ter voz ativa no Legislativo.

Embora existam diferenças na lógica de alocação de financiamento por parte do empresariado, principalmente em se tratando dos incumbents e dos challengers, como no debate norteamericano, no Brasil, a lógica é pautada por uma relação de troca (STIGLER, 1971 apud SANTOS; SILVA; FIGUEIREDO FILHO; ROCHA, 2015): o candidato precisa garantir a sua manutenção no cargo, por meio de votos e, para obtêlos, precisa de recursos para mobilizar o eleitorado. O empresariado, por sua vez, precisa garantir o seu acesso ao poder público, para garantir o acolhimento de suas demandas.

Na prática, porém, o sistema não é hermético, quiçá harmônico. Para tanto, é importante que o pesquisador, por vezes, trabalhe com o contrafactual. No presente caso, serão analisados não somente os casos em que os parlamentares trabalharam em consonância com os anseios da indústria, mas também os casos em que os interesses do governo possivelmente influenciaram o posicionamento dos parlamentares, ou seja, foram conflitantes com o dos financiadores. 
Para proceder a esta análise, portanto, é interessante tratar do momento histórico, mesmo que brevemente, sobre a relação do Executivo com o Legislativo, à época do recorte temporal desta dissertação. Desde o segundo governo de Lula (20072010), o Partido dos Trabalhadores (PT) batalhou para estreitar seus laços com o empresariado, esforço que culminou em um bom relacionamento dos parlamentares da base do governo com os anseios da indústria, no governo posterior de Dilma Rousseff (2011-2014) (BRESSER-PEREIRA, 2013).

Muito além da vertente puramente ideológica, é necessário levar em conta as mudanças trazidas pela Constituição Federal de 1988, que aumentou a gama de poderes, inclusive legislativos, à chefia do Executivo. Tal fato faz com que muitos autores (KREHBIEL, 1991; SHUGART; CAREY, 1992 apud FIGUEIREDO; LIMONGI, 1995; PEREIRA; POWER; RENNÓ, 2005; ARAÚJO; SILVA, 2013) defendam o argumento que de o governo cumpre o papel de agenda setter do Legislativo, comportamento corroborado pelos aspectos organizacionais da Câmara dos Deputados.

A preponderância do Executivo sobre o processo legislativo é, portanto, privilegiada pelas vantagens institucionais que viabilizam este tipo de comportamento (FIGUEIREDO; LIMONGI, 1995). Justifica-se tal fato, em parte, pela manutenção, na Constituição de 1988, dos poderes auferidos ao presidente à época do governo militar pela Constituição de 1946, fazendo com que este fosse a principal fonte de iniciativa legislativa.

Não obstante as prerrogativas institucionais, o desenho de um cenário de conflito ou cooperação entre os interesses do Executivo e do Legislativo é dependente da capacidade de diálogo entre ambos. Nas conclusões de Figueiredo e Limongi (1995):

Ainda que ineficiente do ponto de vista organizacional, a forma como os trabalhos estão organizados [no Legislativo] favorecem o Executivo. Ao dispor de uma instância centralizada para negociar, o Colégio de Líderes, o Executivo vê minimizadas as incertezas e dificuldades próprias a uma negociação descentralizada. O Executivo passa a se relacionar diretamente com o Colégio de Líderes, a quem também interessa, para firmar sua liderança institucional, reduzir as incertezas do conflito político. 
[...] A cooperação do Legislativo para com os projetos presidenciais de fato apresentados não garante a cooperação para toda e qualquer iniciativa presidencial. Posto de outra forma: o presidente não envia projetos a partir da antecipação das dificuldades que estes enfrentariam. Sabendo-se derrotado e agindo de maneira estratégica, o presidente se cala.

Para que seja possível aferir se, de fato, os interesses do governo são conflitantes com os do empresariado, em um primeiro momento, é necessário analisar o financiamento eleitoral destinado aos parlamentares envolvidos nas proposições da Pauta Mínima da CNI, categorizando-os entre governo e oposição, como mostra a Tabela 5:

Tabela 5 - Montante do financiamento de campanhas - Governo versus Oposição

\begin{tabular}{|c|c|c|c|c|c|}
\hline Posicionamento & $\begin{array}{c}\text { Número } \\
\text { de } \\
\text { deputados }\end{array}$ & $\begin{array}{c}\text { Montante do } \\
\text { financiamento } \\
\text { geral }\end{array}$ & $\begin{array}{c}\text { Porcentagem } \\
\text { em relação } \\
\text { ao total geral }\end{array}$ & $\begin{array}{c}\text { Montante do } \\
\text { financiamento } \\
\text { empresarial }\end{array}$ & $\begin{array}{c}\text { Porcentagem } \\
\text { em relação } \\
\text { ao total geral }\end{array}$ \\
\hline Governo & 181 & $\begin{array}{c}\mathrm{R} \$ \\
155.287 .350,91\end{array}$ & $62,38 \%$ & $\mathrm{R} \$$ & $67.709 .684,94$ \\
\hline Oposição & 58 & $\begin{array}{c}\mathrm{R} \$ \\
93.668 .256,87\end{array}$ & $37,62 \%$ & $\begin{array}{c}\mathrm{R} \$ \\
53.915 .864,98\end{array}$ & $44,33 \%$ \\
\hline Total & $\mathbf{2 3 9}$ & $\begin{array}{c}\mathbf{R} \$ \\
\mathbf{2 4 8 . 9 5 5 . 6 0 7 , 7 8}\end{array}$ & $\mathbf{1 0 0 \%}$ & $\begin{array}{c}\mathbf{R} \$ \\
\mathbf{1 2 1 . 6 2 5 . 5 4 9 , 9 2}\end{array}$ & $\mathbf{1 0 0 \%}$ \\
\hline
\end{tabular}

Fonte: Elaboração própria.

De acordo com a Tabela 5, é possível observar que o número de parlamentares que foram classificados como atores nas proposições da CNI e que, ao mesmo tempo, faziam parte da base de apoio ao governo, é imensamente maior (75\%) ao número de parlamentares que se encontravam na oposição, o que é positivo para a presente análise. É importante ressaltar que, de acordo com o que fora observado ao se colherem os dados para a classificação dos parlamentares, ser da base de apoio ao governo não necessariamente significa acompanhar o posicionamento deste. $\mathrm{O}$ que tem mais peso no comportamento parlamentar, na dicotomia governo versus empresariado, portanto, é o 
que será com o auxílio da Análise Qualitativa Comparativa $\left(\mathrm{QCA}^{11}\right)$, em capítulo posterior.

O montante do financiamento destinado aos parlamentares classificados enquanto "governo", portanto, foi maior que o dos parlamentares da "oposição", tendo em vista o número que compõe cada grupo. Isso fica claro quando se observa a proporção em relação ao total geral do financiamento, incluindo todas as espécies de doações recebidas pelos parlamentares, incluindo a doação oriunda de pessoas jurídicas. Porém, quando é isolada a categoria de financiamento exclusivamente empresarial, nota-se que, proporcionalmente, a diferença não é tão discrepante assim entre o montante destinado unicamente aos 58 parlamentares da oposição: menos de doze pontos percentuais.

No pleito de 2010, é possível observar uma tendência no financiamento empresarial setorial ou, em outras palavras, no dinheiro destinado aos diferentes ramos da economia que estão representados na Câmara via frentes parlamentares, apontada por Machado (2013) em estudo sobre a Frente Parlamentar da Agropecuária, bem como por Santos (2012): os parlamentares da oposição receberam mais financiamento de origem empresarial que os partidos da situação, como o PT, a título de exemplo, embora tenham sido eleitos em menor número. A avaliação do partido do governo, à época da eleição, explica parte desse posicionamento. Porém, como será mostrado adiante, houve uma aproximação entre o empresariado e os deputados da base governista no quadriênio 2011-2014, proporcionada pela avaliação positiva que o governo apresentou ao longo do período em estudo.

\footnotetext{
${ }^{11}$ Da sigla em inglês, Qualitative Comparative Analysis. Será utilizada, para fins de referência ao longo deste estudo, a expressão em sua língua de origem.
} 


\section{4 - A CNI ENQUANTO REPRESENTANTE DO EMPRESARIADO INDUSTRIAL NO BRASIL}

A CNI é o órgão máximo de representação do setor industrial brasileiro. Fundada em 1938, tem como um dos principais papeis a defesa dos interesses da indústria junto aos poderes Executivo, Legislativo e Judiciário, bem como a persecução direta desses interesses, traduzidos, pelos estudiosos da área, enquanto atividades de lobby.

Embora amplamente reconhecida e estudada pelo papel desempenhado junto ao Legislativo na defesa de sua agenda política, no presente estudo, a CNI será tratada não como uma instituição que faz lobby, mas como a representante dos interesses do empresariado industrial junto à Câmara dos Deputados, tendo em vista que este ator atuou previamente enquanto financiador de campanhas.

A Pauta Mínima da Agenda Legislativa da CNI é composta pelos projetos de prioridade máxima da indústria, reunindo todos os projetos prioritários para o setor produtivo que se encontram sob análise do Congresso Nacional ${ }^{12}$. Elaborada anualmente desde 1996, em um seminário que reúne especialistas nas áreas temáticas que envolvem as diversas cadeias produtivas da indústria, representantes setoriais e políticos, o RedIndústria, a Agenda Legislativa da Indústria (ALIn) é o resultado de uma consulta às 27 federações estaduais de indústrias e às associações setoriais de caráter nacional, que congregam na ALIn os seus principais interesses legislativos.

Para a presente pesquisa, o recorte temporal foi delimitado às agendas de 2011 até 2014 , para que se estude a legislatura mais recente ( $54^{\mathrm{a}}$ legislatura), já encerrada, uma vez que o propósito é analisar o comportamento dos parlamentares que agiram em conjunto em uma determinada proposição, fato que seria comprometido, caso se estendesse o recorte temporal. Desse modo, a Pauta Mínima é o principal balizador para rastrear os interesses do empresariado junto à Câmara dos Deputados e aferir o comportamento de cada parlamentar, financiado pelo ramo, no tocante às matérias de interesse da indústria.

Apesar de se referir a um ano específico, a Pauta Mínima de um determinado ano não é composta somente dos projetos que entraram em tramitação naquele referido

\footnotetext{
${ }^{12}$ Fonte: Apresentação Pauta Mínima da Agenda Legislativa de 2014, p.05.
} 
ano, mas os projetos que estão em tramitação, de modo geral, e são de interesse da indústria. Dessa forma, é possível encontrar, em agendas de diferentes anos, projetos de lei que se repetem, bem como as proposições cujo início da tramitação remonta a um ano bem distante da data da agenda.

\section{1 - As proposições prioritárias das Pautas Mínimas da Confederação Nacional da Indústria (2011-2014)}

\subsection{1 - Seleção das proposições}

Por conta do recorte temporal desta dissertação, foram selecionadas apenas as proposições legislativas ${ }^{13}$ cujo início de tramitação é datado de 2011 até 2014 . Das $53^{14}$ proposições, constantes nas Pautas Mínimas do referido período, dezessete se encaixaram no critério estabelecido para a presente análise. Deste total, apenas dez proposições estavam em tramitação na Câmara dos Deputados ${ }^{15}$, quando da seleção da Agenda. Levando em conta que, à época da análise, duas das dez proposições não possuíam nenhum avanço na tramitação, além de sua publicação, excluíram-se também estas. São analisadas, portanto, oito proposições, que se enquadram como Projetos de Lei (PL), Projeto de Lei Complementar (PLP) e Medida Provisória (MP).

Como o objetivo da presente pesquisa é analisar o comportamento esperado do parlamentar, levando em conta sua atuação junto às proposições prioritárias da indústria, não se levarão em conta apenas as proposições com tramitação encerrada, mas também as que estão em tramitação em estágio avançado. Das proposições com tramitação encerrada, três já haviam virado norma jurídica, à época desta análise, como é possível observar na Tabela 6 .

\footnotetext{
${ }^{13}$ De acordo com o RICD, art. 100, classifica-se enquanto proposição a Proposta de Emenda à Constituição (PEC); os projetos de lei de natureza ordinária ou complementar; as emendas de todas as espécies; as indicações, os requerimentos; os recursos, os pareceres e a Proposta de Fiscalização e Controle (PFC).

${ }^{14}$ Valor referente ao total de proposições constantes das Pautas Mínimas de 2011 a 2014, excluídas as proposições que se repetem nas diferentes edições da Agenda Legislativa da Indústria.

${ }^{15}$ Exclui-se, desta análise, os projetos de lei que estavam em tramitação nesta Casa, tendo em vista que não se trata do objeto de análise desta dissertação. Existem, porém, projetos de lei que são originários no Senado Federal na presente análise, mas que se enquadraram enquanto objeto de análise por estar em tramitação na Câmara dos Deputados.
} 
Tabela 6 - Situação das proposições em outubro de 2015

\begin{tabular}{|c|c|}
\hline Situação & Quantitativo \\
\hline Em tramitação & 2 \\
\hline Tramitação encerrada & 6 \\
\hline TOTAL & $\mathbf{8}$ \\
\hline
\end{tabular}

Fonte: Elaboração própria.

\subsection{2 - Panorama das proposições selecionadas}

Para que seja possível compreender o comportamento parlamentar dentro da análise multivariada, é necessário que se saiba quais foram os temas das proposições que pautaram a agenda prioritária da indústria. Este capítulo trata da análise isolada das matérias selecionadas para o presente estudo, bem como informações sobre a sua situação à época da análise e, ocasionalmente, algumas situações que ocorreram no decorrer de sua tramitação, que venham a interessar para os fins a que esta dissertação se destina.

\begin{tabular}{|c|l|}
\hline Proposição & \multicolumn{1}{|c|}{ Resumo $^{\mathbf{1 6}}$} \\
\hline MPV 595/2012 & $\begin{array}{l}\text { A Medida Provisória regula a exploração } \\
\text { pela União, direta ou indiretamente, dos } \\
\text { portos e instalações portuárias, e das } \\
\text { atividades desempenhadas pelos } \\
\text { operadores portuários. A exploração } \\
\text { indireta do porto organizado e das } \\
\text { instalações portuárias neles localizados } \\
\text { ocorrerá por concessão e arrendamento de } \\
\text { bem público. Nas instalações localizadas } \\
\text { fora dos portos organizados, a exploração } \\
\text { ocorrerá mediante autorização. }\end{array}$ \\
\hline
\end{tabular}

Autoria: Poder Executivo

Posicionamento da CNI: Convergente

\footnotetext{
${ }^{16}$ As descrições das proposições foram extraídas das Agendas Legislativas da Indústria. Trata-se de um resumo elaborado sobre o teor proposição e não a exposição de sua ementa, uma vez que esta, por vezes, não consegue esclarecer sobre o que realmente trata uma determinada proposição.
} 
Ano em que configura na Pauta Mínima: 2013

Análise $^{17}$ : A Medida Provisória 595/2012, também conhecida como MP dos Portos, configurou na Pauta Mínima da ALIn no ano de 2013, ano em que a matéria começou a ser, de fato, apreciada. Em sua tramitação na Câmara dos Deputados, a matéria foi amplamente debatida, tendo recebido 645 emendas na Comissão Mista, de autoria de deputados, e 34 emendas em Plenário.

Dos 133 deputados que discursaram em Plenário, foi possível notar que, pelo governo ter interesse direto na proposição, os parlamentares do PT, mesmo partido da presidente Dilma Rousseff, autora da proposição, se mobilizaram para manter a proposição na Ordem do Dia do Plenário, enquanto os partidos de oposição articulavam uma obstrução ao projeto. Em um de seus discursos no Pequeno Expediente ${ }^{18}$, o deputado Paes Landim (PTB/PI) fez uma menção a um artigo publicado no jornal Valor Econômico (26/03/2013), de autoria do então presidente da CNI, Robson Braga de Andrade, elogiando seu posicionamento, em nome da indústria, ao apoiar a MP 595/2012:

[...] A respeito disso, aliás, este excepcional Presidente da Confederação Nacional da Indústria, Robson Braga de Andrade, num belo, conciso e profundo artigo escrito no jornal Valor Econômico do mesmo dia, 26 de março, sob o título "A indústria apoia a MP 595 que regula o setor portuário" [...].

[...] E a sua conclusão, nos seus dois últimos parágrafos, Sr. Presidente, merece realmente reflexão e mostra um grande acerto na medida tomada pela Presidenta Dilma Rousseff, uma decisão de estadista, ao tentar modernizar o sistema portuário brasileiro $[\ldots]^{19}$.

\footnotetext{
17 A análise desta e das demais proposições se dará com base em sua tramitação na Câmara dos Deputados, não sendo abordada sua situação fora da referida Casa Legislativa.

${ }^{18}$ De acordo com o RICD, em seus artigos 79 a 81, o Pequeno Expediente é a "primeira parte da sessão ordinária do Plenário, tem duração máxima de 60 minutos e é destinado às comunicações de parlamentares previamente inscritos".

${ }^{19}$ A íntegra do discurso, bem como o artigo a que o discurso faz referência, podem ser encontrados no Anexo A.
} 
Na Tabela 7 abaixo, é possível analisar como foi o posicionamento dos parlamentares, levando em conta a análise do discurso dos que se pronunciaram em Plenário, acerca da MP dos Portos, levando em conta a sua ideologia (se é ou não da coalizão governista) e, atrelado a isso, se ele votou ou não de acordo com o posicionamento da indústria para essa proposição.

Tabela 7 - Posicionamento parlamentar convergente ou não com a CNI, de acordo com sua ideologia (pró ou contra o governo), na MP 595/2012

\begin{tabular}{|c|c|c|c|}
\hline Coalizão governista & Acompanha CNI & $\begin{array}{c}\text { Número de } \\
\text { parlamentares }\end{array}$ & Porcentagem \\
\hline Sim & Sim & 91 & $68,4 \%$ \\
\hline Sim & Não & 14 & $10,5 \%$ \\
\hline Não & Sim & 11 & $8,2 \%$ \\
\hline Não & Não & 17 & $12,7 \%$ \\
\hline
\end{tabular}

Fonte: Elaboração própria.

De acordo com os dados fornecidos pela tabela, como o posicionamento da CNI para a MP foi convergente com o posicionamento do governo, ou seja, favorável à aprovação da proposição, era de se esperar que grande parte dos parlamentares da base do governo acompanhasse o posicionamento da CNI. Uma ínfima parte dos parlamentares da base não corroborou tal posicionamento, número que chega a se comparar com o da oposição que igualmente não concedeu apoio. $\mathrm{O}$ interessante de se notar, também, foi o grande empenho dos parlamentares da base governista na proposição, tendo em vista o elevado número dos que se posicionaram em Plenário, mesmo com a oposição, cuja atuação foi tímida, indicando a obstrução da matéria.

Após ter sido apreciada em sessão conjunta do Congresso Nacional, a MP $595 / 2012$ foi transformada na Lei Ordinária $12.815 / 2013^{20}$, nos termos em que agradassem à base governista e, em consequência, os interesses do Executivo.

${ }^{20}$ Íntegra da Lei $\mathrm{n}^{\circ}$ 12.815, de 5 de junho de 2013: http://www.planalto.gov.br/ccivil_03/_ato20112014/2013/Lei/L12815.htm. Acesso em 24/11/2015. 


\begin{tabular}{|c|c|}
\hline Proposição & Resumo \\
\hline $\begin{array}{l}\text { MPV 627/2013 } \\
\text { Alteração das normas de tributação de } \\
\text { lucros e dividendos de controladas e } \\
\text { coligadas brasileiras no exterior }\end{array}$ & $\begin{array}{l}\text { A Medida Provisória prevê os efeitos } \\
\text { tributários das alterações societárias e } \\
\text { contábeis decorrentes da adoção dos } \\
\text { padrões contábeis internacionais } \\
\text { (promovida pela Lei n }{ }^{\circ} 11.638 / 2007 \text { ), } \\
\text { revogando o Regime Tributário de } \\
\text { Transição (RTT), instituído pela Lei n } \\
\text { 11.941/2009. A Medida também dispõe } \\
\text { sobre a tributação de lucros auferidos por } \\
\text { intermédio de empresas controladas e } \\
\text { coligadas no exterior. }\end{array}$ \\
\hline
\end{tabular}

Autoria: Poder Executivo

\section{Posicionamento da CNI: Convergente}

\section{Ano em que configura na Pauta Mínima: 2014}

Análise: Alvo de uma recente investigação da Polícia Federal, a Operação Zelotes $^{21}$, deflagrada em outubro de 2015, a Medida Provisória 627/2013 foi alvo de discussões acaloradas no Plenário da Câmara dos Deputados. Com o intuito de alterar a tributação das empresas multinacionais brasileiras, no tocante aos lucros advindos de suas controladas no exterior, a proposição recebeu 513 emendas na Comissão Mista destinada a apreciar a MP, e três emendas de Plenário.

Tendo o governo e as empresas como principais interessados na proposição, o relator na Comissão Especial, deputado Eduardo Cunha (PMDB/RJ), pertencente ao partido da base do governo, atuou como um dos principais atores em Plenário, quando da apreciação da proposição na Câmara dos Deputados. Sem alterar substancialmente o teor da MP, o relator sugeriu a inclusão de novos benefícios para as empresas multinacionais, fato que pode justificar o posicionamento favorável da CNI em relação à proposição.

\footnotetext{
${ }^{21}$ A Operação Zelotes (nome dado em alusão ao adjetivo "zelote", aquele que finge ter zelo) foi deflagrada com o intuito de investigar esquemas de corrupção, no âmbito do Conselho de Administração de Recursos Fiscais (CARF), órgão ligado ao Ministério da Fazenda. Em uma fase mais recente da operação, o foco das investigações foram as possíveis "compras" de Medidas Provisórias por empresas de lobistas, que beneficiariam empresas do ramo automobilístico. Uma das Medidas Provisórias sob investigação é a 627/2013.
} 
Com igual interesse por parte do governo, porém, a Tabela 8 nos mostra que, embora centrada em um pequeno número de atores que se pronunciaram em Plenário, o número de parlamentares da coalizão governista que acompanha o posicionamento da CNI é equiparável ao número dos que não acompanharam. É interessante ressaltar que, embora o número de atores que discutiram a proposição tenha sido reduzido, em relação às demais proposições, esse processo centrou-se nos mesmos atores, que utilizaram a tribuna, por exemplo, até dezoito vezes durante a discussão da MP em Plenário, como foi o caso do relator, deputado Eduardo Cunha.

Tabela 8 - Posicionamento parlamentar convergente ou não com a CNI, de acordo com sua ideologia (pró ou contra o governo), na MP 627/2013

\begin{tabular}{|c|c|c|c|}
\hline Coalizão governista & Acompanha CNI & $\begin{array}{c}\text { Número de } \\
\text { parlamentares }\end{array}$ & Porcentagem \\
\hline Sim & Sim & 18 & $34,6 \%$ \\
\hline Não & Não & 15 & $28,8 \%$ \\
\hline Sim & Não & 12 & $23,0 \%$ \\
\hline Não & Sim & 7 & $13,4 \%$ \\
\hline
\end{tabular}

Fonte: Elaboração própria.

A Medida Provisória 627/2013 foi transformada na Lei Ordinária 12.973/2014, com alterações substanciais do texto original, propostas pelo relator Eduardo Cunha ${ }^{22}$.

\begin{tabular}{|c|l|}
\hline Proposição & \multicolumn{2}{|c|}{ Resumo } \\
\hline PL 037/2011 & $\begin{array}{l}\text { O projeto, na forma do substitutivo } \\
\text { preliminar apresentado pelo relator da } \\
\text { Comissão Especial, estabelece um novo } \\
\text { marco regulatório da atividade de } \\
\text { mineração, abrangendo as atividades de } \\
\text { pesquisa, lavra, desenvolvimento da mina, } \\
\text { beneficiamento, comercialização dos digo de Mineração }\end{array}$ \\
\hline
\end{tabular}

22 Íntegra da Lei $\mathrm{n}^{\circ} 12.973$, de 13 de maio de 2014: http://www.planalto.gov.br/ccivil_03/_ato20112014/2014/Lei/L12973.htm. Acesso em 25/11/2015.

${ }^{23}$ É interessante ressaltar que o referido projeto tem nove apensos. É frequente o debate nos processos legislativos estar centrado em proposições apensadas, e não no projeto principal (que recebeu esta denominação muitas vezes apenas por ser o mais antigo do processo, como previsto regimentalmente). 


\begin{tabular}{|l|l|}
\hline minérios e fechamento da mina. \\
Entre as principais medidas propostas, \\
destacam-se: a definição de novo modelo \\
de regime de aproveitamento dos bens \\
minerais, criação do Conselho Nacional \\
de Política Mineral (CNPM) e da Agência \\
Nacional de Mineração (ANM) e \\
modificação nas alíquotas e base de \\
cálculo da Contribuição Financeira pela \\
Exploração Mineral (CFEM).
\end{tabular}

Autoria: Deputado Weliton Prado (PT/MG)

Posicionamento da CNI: Convergente

Ano em que configura na Pauta Mínima: 2014

Análise: $\mathrm{O}$ projeto de lei que trata sobre o novo Código de Mineração, de autoria do deputado Weliton Prado, da base do governo, que tem como relator o também governista, deputado Leonardo Quintão (PMDB/MG), está em tramitação desde 2011, porém, só entrou na Pauta Mínima em 2014. A proposição ainda se encontra em trâmite no Congresso Nacional, porém, para os fins a que esta análise se destina, a tramitação na 55ª legislatura (2015-2018) não será contabilizada.

Como a proposição esteve sujeita somente à apreciação pelas comissões de mérito e por uma comissão especial com o fim de analisá-la, o parâmetro utilizado para aferir quais foram os parlamentares que agiram e como agiram nesta proposição foram os requerimentos apresentados, no âmbito das comissões, que refletem o posicionamento dos parlamentares, principalmente em sua justificativa. Foram excluídos, desta análise, os requerimentos de apensação e de redistribuição ${ }^{24}$. O relator da proposição, deputado Leonardo Quintão (PMDB/MG), em seu parecer, fez menção aos principais deputados que atuaram no PL 037/2011, bem como seus

\footnotetext{
${ }^{24}$ De acordo com o glossário do sítio da Câmara dos Deputados, apensação é um "instrumento regimental que permite a tramitação conjunta de proposições da mesma espécie que disponha sobre matéria idêntica ou correlata" (RICD, arts. 142 e 143). A redistribuição, por sua vez, ocorre quando "qualquer Comissão pretender que outra se manifeste sobre determinada matéria, apresentará requerimento escrito nesse sentido ao Presidente da Câmara, com a indicação precisa da questão sobre a qual deseja o pronunciamento", após o despacho da matéria às comissões (RICD, art. 140).
} 
posicionamentos. Os parlamentares mencionados também foram contabilizados para a análise.

Tabela 9 - Posicionamento parlamentar convergente ou não com a CNI, de acordo com sua ideologia (pró ou contra o governo), no PL 037/2011

\begin{tabular}{|c|c|c|c|}
\hline Coalizão governista & Acompanha CNI & $\begin{array}{c}\text { Número de } \\
\text { parlamentares }\end{array}$ & Porcentagem \\
\hline Sim & Sim & 15 & $50,0 \%$ \\
\hline Não & Não & 5 & $16,6 \%$ \\
\hline Sim & Não & 2 & $6,6 \%$ \\
\hline Não & Sim & 8 & $26,6 \%$ \\
\hline
\end{tabular}

Fonte: Elaboração própria.

Um total de trinta parlamentares figuram como autores dos 68 requerimentos, em sua grande maioria, para realização de audiências públicas, apresentados no âmbito das comissões, pelas quais o PL 037/2011 tramitou na 54ª legislatura. Destes, a metade votou acompanhando o posicionamento da CNI, sendo, ao mesmo tempo, da base do governo, ao contrário do número dos que simplesmente acompanharam o posicionamento da CNI, que foi baixo. O Executivo sinalizou interesse na proposição, porém, por conta da sua tramitação ainda não ter se encerrado, não é possível aferir se houve, de fato, sucesso ou insucesso do governo frente aos interesses da indústria, no tocante à proposição, como sinalizam os dados supramencionados.

\begin{tabular}{|c|l|}
\hline Proposição & \multicolumn{1}{|c|}{ Resumo } \\
\hline PL 2011/2011 & $\begin{array}{l}\text { Amplia o limite de receita bruta anual } \\
\text { para opção pelo regime de tributação pelo } \\
\text { lucro presumido. Estabelece que poderá } \\
\text { optar pelo lucro presumido a pessoa } \\
\text { jurídica cuja receita bruta total, no ano- } \\
\text { calendário anterior, tenha sido igual ou } \\
\text { inferior a 78 milhões ou a 6,5 milhões, } \\
\text { multiplicado pelo número de meses de }\end{array}$ \\
\hline $\begin{array}{c}\text { Apuração pelo degime do lucro } \\
\text { presumido }\end{array}$
\end{tabular}

\footnotetext{
${ }^{25}$ No referido processo, há seis projetos apensos na Câmara. Esse projeto é considerado regimentalmente o principal, uma vez que foi aprovado pelo Senado Federal. Porém, o relator apresentou substitutivo, não votado, que engloba o PL 2011/2011 e alguns apensos.
} 


\begin{tabular}{|l|l|}
\hline & $\begin{array}{l}\text { atividade do ano-calendário anterior, } \\
\text { quando inferior a doze meses. }\end{array}$ \\
\hline
\end{tabular}

Autoria: Senador ${ }^{26}$ Alfredo Cotait (DEM/SP)

Posicionamento da CNI: Convergente

Ano em que configura na Pauta Mínima: 2012; 2013

Análise: Entre as proposições em análise, o Projeto de Lei 2011/2011, originário do Senado, é a proposição que menos teve avanços. Com a tramitação estagnada desde 2013, ano em que figurou pela última vez na Pauta Mínima, o que se observa é que grandes foram os esforços para que a proposição não avançasse, tendo em vista os pedidos de vista e o requerimento de retirada de pauta, em um acordo de lideranças, na única comissão em que havia recebido um parecer favorável. O posicionamento dos poucos parlamentares que aparecem como atores ativos na presente proposição é bem diverso: a metade acompanha a posição da CNI, sendo que a outra metade age contrariamente.

\begin{tabular}{|c|l|}
\hline Proposição & \multicolumn{1}{|c|}{ Resumo } \\
\hline PL 2126/2011 & $\begin{array}{l}\text { Regulamenta o uso da internet no Brasil e } \\
\text { estabelece as diretrizes a serem seguidas } \\
\text { pelos entes federados, especificando } \\
\text { princípios, objetivos e direitos e garantias } \\
\text { do usuário. }\end{array}$ \\
\hline Marco civil da internet
\end{tabular}

Autoria: Poder Executivo

Posicionamento da CNI: Convergente

Ano em que configura na Pauta Mínima: 2014

Análise: Transformado na Lei $n^{\circ} 12.965$, de 23 de abril de $2014^{27}$, o então projeto de lei visando "estabelecer princípios, garantias, direitos e deveres para o uso da Internet no

\footnotetext{
${ }^{26}$ Apesar de algumas proposições terem origem no Senado Federal, a CNI as listou quando já estavam em tramitação na Câmara dos Deputados. Para essa análise, portanto, não se levará em conta a autoria, tendo em vista que a sua casa de origem não é objeto deste estudo.
} 
Brasil", como assinala sua ementa, inicialmente teve um dos principais partidos da base de apoio ao governo, o Partido do Movimento Democrático Brasileiro (PMDB), atuando como um dos seus principais rechaçadores, ao lado de partidos de oposição, como o Partido da Social Democracia Brasileira (PSDB), contrário à regulamentação da neutralidade da Internet.

Tendo o governo como principal interessado na proposta, a escolha do relator, deputado Alessandro Molon (PT/RJ), foi estratégica, uma vez que ele conseguiu consenso na base aliada para votar favoravelmente a proposta do marco civil da Internet, como sinalizou o governo e também a CNI.

Tabela 10 - Posicionamento parlamentar convergente ou não com a CNI, de acordo com sua ideologia (pró ou contra o governo), no PL 2126/2011

\begin{tabular}{|c|c|c|c|}
\hline Coalizão governista & Acompanha CNI & $\begin{array}{c}\text { Número de } \\
\text { parlamentares }\end{array}$ & Porcentagem \\
\hline Sim & Sim & 53 & $59,5 \%$ \\
\hline Não & Não & 15 & $16,8 \%$ \\
\hline Sim & Não & 13 & $14,6 \%$ \\
\hline Não & Sim & 8 & $8,9 \%$ \\
\hline
\end{tabular}

Fonte: Elaboração própria.

Seguindo a tendência das proposições previamente analisadas, nota-se que o número de parlamentares que acompanham o posicionamento da $\mathrm{CNI}$ e, ao mesmo tempo, são da base do governo, é discrepantemente alto, em relação aos demais posicionamentos. Tal evento pode sinalizar duas tendências: a indústria tende a acompanhar o governo nas pautas mais delicadas, ou o governo tende a agir com maior afinco quando a proposição agrada a seus financiadores de campanha.

\begin{tabular}{|c|l|}
\hline Proposição & \multicolumn{1}{|c|}{ Resumo } \\
\hline PL 3155/2012 & $\begin{array}{l}\text { Dispõe sobre tributação de investimentos } \\
\text { estrangeiros em títulos públicos e de }\end{array}$ \\
\hline Tributação da distribuição de lucros e
\end{tabular}

27 Íntegra da Lei n ${ }^{\circ} 12.965$, de 23 de abril de 2014: http://www.planalto.gov.br/ccivil_03/_ato20112014/2014/lei/l12965.htm. Acesso em: 27/11/2015. 


\begin{tabular}{|l|l|}
\hline dividendos & distribuição de lucros e dividendos. \\
& $\begin{array}{l}\text { Extingue a dedução dos juros sobre capital } \\
\text { próprio para efeito de cálculo do lucro } \\
\text { real. }\end{array}$ \\
\hline
\end{tabular}

Autoria: Deputados Amauri Teixeira (PT/BA); Assis Carvalho (PT/PI); Cláudio Puty (PT/PA); Jilmar Tatto (PT/SP); José Guimarães (PT/CE); Paulo Teixeira (PT/SP); Pedro Eugênio (PT/PE); Pepe Vargas (PT/RS); Ricardo Berzoini (PT/SP)

\section{Posicionamento da CNI: Divergente}

Ano em que configura na Pauta Mínima: 2012

Análise: O PL 3155/2012, que "revoga a isenção de Imposto de Renda em três operações financeiras, aumentando a tributação de empresários, de empresas e de investidores estrangeiros" ${ }^{\text {,28 }}$, é de autoria coletiva de nove deputados do PT. De acordo com a sua tramitação no sítio da Câmara dos Deputados, antes mesmo de receber o despacho para as comissões de mérito, os deputados signatários da proposição apresentaram um requerimento para retirá-la de tramitação ${ }^{29}$, sendo arquivada cinco meses após a sua apresentação. O curioso é que se trata da única proposição para a qual a CNI sinalizou posicionamento contrário, entre as em análise neste estudo, ao mesmo tempo em que é de autoria de deputados governistas.

\begin{tabular}{|c|l|}
\hline Proposição & \multicolumn{1}{|c|}{ Resumo } \\
\hline PLP 200/2012 $^{\mathbf{3 0}}$ & $\begin{array}{l}\text { Determina que a contribuição adicional de } \\
\text { Extinção da contribuição adicional de } \\
10 \% \text { do FGTS }^{31}\end{array}$ \\
& $\begin{array}{l}\text { ao FGTS será extinta após } 1^{\mathbf{0}} \text { de junho de } \\
2013 .\end{array}$ \\
\hline
\end{tabular}

28 Síntese do projeto de lei extraída de notícia veiculada pela Agência Câmara de Notícias. http://www2.camara.leg.br/camaranoticias/noticias/ECONOMIA/409693-PROJETO-REVOGA-TRESISENCOES-DE-IMPOSTO-DE-RENDA.html. Acesso em 30/11/2015.

${ }^{29} \mathrm{O}$ requerimento de retirada de proposição de autoria coletiva foi apresentado com base no art. $104, \S 2^{\circ}$ do RICD, que diz ser necessário metade mais um dos subscritores da proposição para retirá-la de pauta.

${ }^{30}$ Para o PLP 200/2012, não foi possível obter as informações sobre os parlamentares que atuaram na proposição, uma vez que o sítio da Câmara dos Deputados, que hospeda o banco de dados sobre os Discursos e Notas Taquigráficas, reportou erro para duas das páginas de discursos dos parlamentares que utilizaram a tribuna para se manifestar sobre a proposição.

${ }^{31}$ Acrônimo de Fundo de Garantia por Tempo de Serviço. 
Autoria: Senador Renato Casagrande (PSB/ES)

\section{Posicionamento da CNI: Convergente}

Ano em que configura na Pauta Mínima: 2013

Análise: Durante a sua tramitação na Câmara dos Deputados, foi possível visualizar que o Projeto de Lei Complementar 200/2012 foi alvo de obstruções por parte da oposição. Em um esforço de se pautar a matéria, os partidos da base aliada apresentaram requerimentos para incluí-la na Ordem do $\mathrm{Dia}^{32}$ do Plenário e também solicitaram urgência em sua apreciação, uma vez que o Poder Executivo sinalizou interesse na proposição, assim como a CNI. Por conta disso, a discussão da matéria em Plenário foi longa, pois apesar de estarem registrados os discursos de 75 parlamentares, alguns destes chegaram a se pronunciar por doze vezes.

O deputado Mauro Benevides (PMDB/CE) fez menção à CNI em seus dois pronunciamentos em Plenário sobre a proposição. Em ambos, o deputado não deixa transparecer sua opinião, mas sim faz incitações sobre o interesse da CNI na matéria, como em um dos pronunciamentos, onde divulga o evento de lançamento da Agenda Legislativa da Indústria de 2013, ano em que a proposição figurou na Pauta Mínima:

[...] Sabe-se que a maior atenção dos industriais direciona-se para o Projeto de Lei Complementar $n^{\circ} 200$, de 2012, que trata da extinção da contribuição social de multa adicional de $10 \%$ do FGTS, devida pelos empregadores em caso de demissão sem justa causa. Como setor vital para a recuperação de nosso desenvolvimento, a indústria tem enfrentado dificuldades decorrentes da própria conjuntura, cabendo ao Poder Central colaborar para o surgimento de um segmento decisivo para a vitalização do nosso progresso e bem-estar social [...].

[...] Predispomo-nos a acolher as ponderações da atuante CNI, na certeza de que se contribuirá, desta forma, para incentivar o crescimento do próprio País, na superação desta fase delicada por que passa a nossa Nação, apesar da diligente atuação de uma gestora

\footnotetext{
${ }^{32}$ Por se tratar de um Projeto de Lei Complementar, a matéria vai necessariamente a Plenário. De acordo com o glossário do sítio da Câmara dos Deputados, a Ordem do Dia é a "fase da sessão plenária ou da reunião de comissão destinada à discussão e à votação das proposições em pauta. Corresponde, também, à relação de assuntos a serem tratados em uma reunião legislativa” (RICD, arts. 82 a 86).
} 
competente, como a que dirige os nossos destinos, com aprumo e clarividência inquestionáveis.

Apesar de evitar se posicionar sobre a CNI, é claro o posicionamento do deputado em defesa do Poder Executivo, neste pronunciamento e em outro, cinco meses após o primeiro, onde faz menção ao presidente da CNI, Robson de Andrade. Neste, é possível confirmar o alto interesse da indústria pela proposição em estudo, bem como seu posicionamento em relação ao texto inicial da matéria e a sua mobilização em torno da proposição:

[...] Uma das matérias mais controvertidas continua a ser a multa do FGTS, com o posicionamento pela rejeição endossado por entidades empresariais, através de seus órgãos mais representativos, inclusive a poderosa Confederação Nacional da Indústria, presidida pelo líder Robson Braga de Andrade. É muito provável que o comparecimento, nesta terça-feira, possa ser dos mais significativos, em razão também de outros itens que serão submetidos ao crivo final e decisivo dos legítimos representantes populares $[\ldots]^{33}$.

Tabela 11 - Posicionamento parlamentar convergente ou não com a CNI, de acordo com sua ideologia (pró ou contra o governo), no PLP 200/2012

\begin{tabular}{|c|c|c|c|}
\hline Coalizão governista & Acompanha CNI & $\begin{array}{c}\text { Número de } \\
\text { parlamentares }\end{array}$ & Porcentagem \\
\hline Sim & Sim & 38 & $50,6 \%$ \\
\hline Não & Sim & 24 & $32,0 \%$ \\
\hline Sim & Não & 11 & $14,6 \%$ \\
\hline Não & Não & 2 & $2,6 \%$ \\
\hline
\end{tabular}

Fonte: Elaboração própria.

Assim como nas proposições anteriores, o número de parlamentares que acompanham a CNI e, ao mesmo tempo fazem, parte da coalizão governista é superior ao número de parlamentares que não fazem parte da base do governo, mas que igualmente acompanham o posicionamento da CNI. Neste caso em específico, ficou notório, ao analisar a tramitação, o alto interesse tanto do governo quanto da indústria,

${ }^{33}$ Os Anexos C e D trazem a íntegra dos dois discursos mencionados. 
bem como o esforço dos partidos de oposição em tentar obstruir a apreciação da matéria. Apesar dos esforços, o texto aprovado pela Câmara dos Deputados foi vetado pela presidente Dilma Rousseff, sendo o veto mantido pela Comissão Mista incumbida de relatá-lo. A matéria, portanto, foi arquivada, prevalecendo o interesse do Executivo para esta proposição.

\begin{tabular}{|c|c|}
\hline Proposição & Resumo \\
\hline $\begin{array}{c}\text { PLP 237/2012 } \\
\text { Limitação à substituição tributária de } \\
\text { Micro e Pequena Empresas e inclusão de } \\
\text { novas categorias no Simples }\end{array}$ & $\begin{array}{l}\text { Inovações de repercussão geral na Lei } \\
\text { Geral da Micro e Pequena Empresa e no } \\
\text { Simples Nacional: } \\
\text { • inclusão de atividades no Simples; } \\
\text { - Cadastro Nacional Único; } \\
\text { - fiscalização orientadora e dupla visita; } \\
\text { - redução de burocracia; } \\
\text { - vedação da exclusão do Simples } \\
\text { Nacional; } \\
\text { - redução de multas; } \\
\text { - compras governamentais; } \\
\text { - benefícios fiscais; } \\
\text { - substituição tributária. }\end{array}$ \\
\hline
\end{tabular}

Autoria: Deputados Antonio Balhmann (PSB/CE); Antonio Carlos Mendes Thame (PSDB/SP); Leonardo Quintão (PMDB/MG); Otavio Leite (PSDB/RJ); Pedro Eugênio (PT/PE); Ronaldo Zulke (PT/RS); Sandro Alex (PPS/PR)

Posicionamento da CNI: Convergente

Ano em que configura na Pauta Mínima: 2014

Análise: O PLP 237/2012 inicialmente chama a atenção pela diversidade partidária dos autores, que são tanto do governo, quanto da oposição. Por se tratar de uma matéria que altera a Lei da Microempresa (ou Lei do Supersimples), é de se esperar que essa proposição tenha sido sinalizada com prioridade pela CNI. Por ter tramitado somente na 
Comissão Especial destinada a proferir parecer para esse processo, foram utilizados os requerimentos apresentados pelos parlamentares no âmbito desse órgão colegiado.

Tendo em vista a sua breve tramitação, uma vez que a proposição foi declarada prejudicada $^{34} 35$, um número reduzido de atores foi contabilizado nesta matéria. Apesar da prejudicialidade, a temática foi contemplada pelo PLP principal, não listado pela CNI, vindo a se transformar em lei em 2014, ano em que o apensado em estudo figurou na Pauta Mínima.

\footnotetext{
34 De acordo com o sítio da Câmara dos Deputados, em seu glossário de termos técnicos, a prejudicialidade de uma proposição é uma "situação prevista no Regimento Interno da Câmara dos Deputados que impede a sujeição de uma proposição a votos, determinando seu arquivamento sem deliberação" (RICD, arts. 163 e 164).

35 No conteúdo, a proposta foi aprovada. O substitutivo do relator considerava aprovados os dois projetos. Houve uma emenda substitutiva global em Plenário, fruto de negociação política (englobando os projetos e as propostas surgidas no Plenário). Só o texto dessa emenda global aprovada é que tramitou, a partir de então. Os apensos, por sua vez, são sempre prejudicados nesta etapa. Ocorreria a mesma coisa, portanto, se o primeiro substitutivo do relator tivesse sido aprovado.
} 


\section{5 - ANÁLISE DAS CATEGORIAS DE COMPORTAMENTO}

\section{1 - A escolha do método: Qualitative Comparative Analysis (QCA)}

Ainda pouco difundido no Brasil, o método de análise configuracional é utilizado pela literatura da ciência política, em âmbito internacional, para estabelecer comparações em contextos de multicausalidade, onde não exista uma só causa que explique um dado fenômeno. O método trata de casos simultâneos que, dependendo da forma como se combinam (ausência ou presença de uma condição), podem explicar, de maneira associada, um determinado outcome $e^{36}$, diferentemente dos métodos estatísticos mais usualmente utilizados pela literatura nacional: "o teste na análise comparativa qualitativa é feito a partir de todas as condições em conjunto e não a partir da medição do efeito de uma variável particular sobre o outcome" (FREITAS; BIZZARRO NETO, 2014).

Em se tratando de QCA, portanto, deve-se pensar em outcomes qualitativos (mudanças ou descontinuidades observáveis), não em variáveis dependentes, uma vez que estas não são diferenciáveis ou calibráveis, como se pretende no método comparativo. O Quadro 1 mostra um breve comparativo entre as peculiaridades dos métodos quantitativos tradicionalmente utilizados na ciência política e o método de análise comparativa qualitativa:

\section{Quadro 1 - Métodos Quantitativos versus QCA}

\begin{tabular}{|c|c|}
\hline Métodos Quantitativos & QCA \\
\hline Exige robustez teórica & Exige robustez teórica \\
\hline Evita explicações individuais & Evita explicações individuais \\
\hline Ferramenta replicável e formalizada & Ferramenta replicável e formalizada \\
\hline Amostra aleatória & $\begin{array}{c}\text { Seleção intencional dos casos, para incluir } \\
\text { casos típicos, exceções e/ou outliers. }\end{array}$ \\
\hline Generalização estatística & $\begin{array}{c}\text { Generalização modesta, limitada no tempo e no } \\
\text { espaço. }\end{array}$ \\
\hline
\end{tabular}

\footnotetext{
${ }^{36}$ Nas palavras de Ragin (2008), “An important key to assessing outcomes, as opposed to dependent variables, is that they should involve explicit criteria and also should be calibrated. That is, researchers should use external, substantive criteria to define the phenomenon of interest and to evaluate its degree of expression. In general, defining qualitative outcomes requires much more researcher input than simply selecting a dependent variable”.
} 


\begin{tabular}{|c|c|}
\hline Causalidade única ou múltipla & Causalidade múltipla conjuntural \\
\hline Universalidade ou equifinalidade & Equifinalidade \\
\hline Unifinalidade & Multifinalidade \\
\hline Relações lineares causais e aditividade & Relações constitutivas e não aditivas \\
\hline Simetria causal & Assimetria causal \\
\hline $\begin{array}{c}\text { Desmembra os casos em um conjunto de } \\
\text { variáveis independentes. }\end{array}$ & $\begin{array}{c}\text { Desmembra casos em um conjunto de atributos } \\
\text { inter-relacionados. }\end{array}$ \\
\hline $\begin{array}{c}\text { Foco nas variáveis e nas relações entre } \\
\text { variáveis causais e dependentes. }\end{array}$ & $\begin{array}{c}\text { Foco em configurações de variáveis que } \\
\text { resultem em diferentes resultados. }\end{array}$ \\
\hline $\begin{array}{c}\text { Número de vezes que a variável independente } \\
\text { é observada é relevante (quantificação das } \\
\text { ocorrências). }\end{array}$ & $\begin{array}{c}\text { Número de observações dos atributos não é } \\
\text { relevante (não há quantificação de ocorrências) }\end{array}$ \\
\hline $\begin{array}{c}\text { Casos podem ser analisados de forma } \\
\text { anônima. Possível manipulação de variáveis. }\end{array}$ & $\begin{array}{c}\text { Casos são conhecidos e manipulados. Há } \\
\text { vista como um incremento substantivo do } \\
\text { conhecimento teórico. }\end{array}$ \\
\hline
\end{tabular}

Fonte: Gurgel (2011), "com base em resumo elaborado a partir dos livros Configurational comparative methods de Rihoux e Ragin (2009) e Redesigning social inquiry, de Ragin (2008)".

Conhecido por seu acrônimo QCA (do inglês, qualitative comparative analysis), a ferramenta foi criada por Charles Ragin, em 1987, em seu modelo mais básico, que utiliza o método dicotômico, baseada na álgebra booleana, que foi sendo aperfeiçoado por ele e por demais autores posteriormente.

O modelo básico deu origem ao crisp-set QCA, método escolhido para o desenvolvimento desta dissertação. Pensado para a análise de um número relativamente pequeno de casos (10>n>100), (RIHOUX; MARX, 2013 apud FREITAS; BIZZARRO NETO, 2014), uma vez que parte da análise de relações de suficiência e causalidade entre as condições (ou fatores causais) estabelecidas, o método é ideal para analisar conceitos abstratos de forma comparada, uma vez que a lógica binária booleana faz com que as características quantitativas e qualitativas das condições estabelecidas para o teste de teoria se preservem, sintetizando-as, mas resguardando a complexidade de cada caso ou variável (FREITAS; BIZZARRO NETO, 2014). Nessa linha: 
Ragin $(1987 ;$ 1994) pretendeu desenvolver uma estratégia que sintetizasse estudos orientados a caso, ou qualitativos, e estudos orientados a variáveis, ou de abordagem quantitativa, integrando as melhores características das duas abordagens. Dessa forma, a QCA foi elaborada e utilizada para interpretar casos, no sentido de permitir uma comparação que combinasse as variáveis selecionadas.

O lado qualitativo da QCA expressa-se por sua abordagem holística, em que cada caso é individualmente considerado uma entidade complexa, que precisa ser devidamente compreendida na sua expressão total, e que não deve ser esquecida no curso da análise (SILVA, 2013).

Por conta da álgebra booleana, as variáveis assumem valores binários, que, no caso do crisp-set QCA, são de 0 (ausência/não) ou 1 (presença/sim). A calibragem dos valores, por sua vez, é dependente do pesquisador, uma vez que, ao trabalhar com o método configuracional, este deve se amparar nas condições já estabelecidas pela teoria. Uma vez na truth-table (do inglês, tabela verdade), é possível visualizar todas as combinações entre as condições, que geram um dado outcome, a partir de condições previamente selecionadas (RIHOUX; MEUR, 2009 apud FREITAS; BIZZARRO NETO, 2014). De acordo com Ragin (1994) apud Freitas e Bizzarro Neto (2014), a truth-table classifica as diferenças e as semelhanças entre os conjuntos de casos de uma forma concisa, resumida, de acordo com as combinações de valores possíveis.

No entendimento de Freitas e Bizzarro Neto (2014):

O método, portanto, favorece o estreitamento entre teoria e empiria, pois a conexão entre as causas e os efeitos não devem ocorrer apenas intuitivamente, mas devem ser fundamentadas teoricamente, de forma a testar, confirmar, refutar e reconstruir teorias, caso necessário.

Apesar de existirem diferentes métodos dentro do rótulo QCA, um intermediário ( $m v Q C A)$ e um mais complexo $\left(f_{s} Q C A\right)$ que o que será utilizado nesta dissertação, em termos de utilização de valores, todas foram criadas sob um mesmo propósito, nas palavras de Freitas e Bizzarro Neto (2014):

Em resumo, as técnicas de QCA servem para cinco propósitos, de acordo com Berg-Schlosser, Meur, Rihoux e Ragin (2009): 1) 
sumarizar dados, que seria o uso mais descritivo do método, através da geração (através do software) da tabela-verdade ou truth-table, podendo encontrar similares e diferenças entre os casos; 2) conferir coerência dos dados, detectando nos casos configurações contraditórias ao modelo, ou seja, que apresentam relações não esperadas entre as condições e o outcome; 3) testar hipóteses ou teorias existentes; 4) testes de conjecturas formuladas pelo pesquisador, tentando uma teoria ad hoc ou parte de uma teoria, explorando, assim, os casos em análise; 5) e desenvolver novos argumentos teóricos na forma de hipóteses, o que corresponde à finalidade de qualquer empreendimento acadêmico: conectar os casos às teorias.

Tendo em vista a breve apresentação da metodologia escolhida para a análise dos dados desta dissertação, justifica-se, assim, a sua escolha. A análise das possíveis condições que podem influenciar o comportamento de um parlamentar ao acompanhar, ou não, as orientações da CNI, não pode estar dissociada dos ruídos que esse tipo de análise carrega consigo, uma vez que não é somente um fator que pode vir a exercer influência sobre o comportamento, mas um conjunto de fatores que, ao serem analisados isoladamente, na condição de variáveis dependentes, não geram o mesmo outcome se analisados de forma agregada, tendo em vista que se trata de um fenômeno multicausal. As técnicas puramente quantitativas fazem com que as variáveis assumam, entre si, relações aditivas ou multiplicativas, que podem ser insuficientes para explicar o comportamento parlamentar, tendo em vista a universalidade de causas combinadas que possam explicá-lo.

\section{2 - A Pauta Mínima da CNI em dados}

\subsection{1 - Categorias de comportamento}

A fim de transformar as informações da Pauta Mínima da Agenda Legislativa da Indústria em dados, foi necessário selecionar criteriosamente as variáveis para a montagem do banco de dados, a fim de subsidiar a análise multivariada. Para tanto, 
foram criadas oito ${ }^{37}$ categorias de comportamento, que ajudam a explicar a pergunta de pesquisa e, ao mesmo tempo, tentam evitar vieses na análise.

\section{Categoria 1 - Posicionamento da CNI:}

Os interesses da CNI em uma dada proposição são sinalizados na própria Agenda Legislativa da Indústria, em quatro categorias: Convergente; Convergente com ressalvas; Divergente; Divergente com ressalvas. As ressalvas poderiam ser usadas como uma maneira de refinar a análise. Porém, para os fins a que essa análise se dedica, foi adotada a dicotomia Convergente ou Divergente, uma vez que essa categorização está sendo usada para aferir o grau de afinidade do parlamentar à agenda da indústria, não o sucesso ou insucesso dessa agremiação na defesa de seus interesses. Além disso, a binariedade das categorias é condicionada pela análise via crisp-set QCA.

\section{Categoria 2 - Acompanha ou não o posicionamento da CNI em uma dada} proposição:

Essa categoria, que foi escolhida como o outcome da presente análise, leva em conta como o parlamentar se posicionou diante de uma determinada proposição, tendo como base a sinalização da CNI. Ou seja, a dicotomia Sim ou Não utilizada não se refere à aprovação ou rejeição da matéria em análise, mas se ele acompanhou o posicionamento da CNI, sinalizado na Agenda Legislativa, para aquela proposição.

Para verificar a atuação parlamentar nas proposições selecionadas, foi feita a análise dos discursos dos deputados que utilizaram deste recurso em Plenário e também o teor dos requerimentos apresentados. Importante ressaltar que os requerimentos analisados foram os de retirada de pauta, pedido de audiência pública, pedido de vista, adiamento de discussão e votação, inclusão na ordem do dia, pedido de urgência. Excluíram-se desta análise os requerimentos de solicitação de tramitação conjunta (apensamento) e de redistribuição, por não se enquadrarem enquanto manobras de ação relevantes para o presente estudo. Tais fatores foram utilizados para diferenciar os parlamentares que não apenas votaram em uma dada proposição, mas que, de certa maneira, agiram por ela, seja para sua aprovação ou rejeição, atuaram no processo legislativo em questão.

\footnotetext{
${ }^{37}$ A categoria 1 foi utilizada somente para embasamento da categoria 2, não entrando, portanto, na análise propriamente dita.
} 
Categoria 3 - Perfil do parlamentar (profissão): se é industriário ou empresário:

Uma maneira de se eliminarem possíveis vieses na análise do grau de apoio é verificando o background do parlamentar, ou seja, os motivos que os levam a apoiarem a agenda da indústria: 1) porque receberam financiamento da indústria; 2) porque são industriais; 3) porque simpatizaram com a causa ou 4) porque já existia predisposição do parlamentar para votar de uma determinada maneira (WAWRO, 2001), mais difícil de contabilizar. Para tal, faz-se necessário coletar informações sobre o perfil do parlamentar, disponível no sítio da Câmara dos Deputados, para ajudar a entender a sua atuação. Foram contabilizados como pertencentes ao ramo da indústria os parlamentares que declararam, em seu perfil parlamentar, ser industriários ou empresários.

\section{Categoria 4 - Ideologia do parlamentar: se é governo ou oposição:}

A orientação ideológica (pró ou contra o governo) é uma maneira interessante de controlar o grau de apoio à Agenda Legislativa da Indústria, uma vez que, é possível aferir se, quando colocado em momentos de confronto de interesses, o que pesa mais para o parlamentar: se a sua ideologia, traduzida no pertencimento à base governista ou não, ou o posicionamento pessoal, independentemente da sinalização do seu bloco.

A proximidade dos parlamentares com as causas do governo (mais ou menos fiéis à agenda deste) pode vir a gerar ruídos na análise, se esta for pautada somente se levadas em conta o posicionamento do parlamentar como apoio à indústria e ignorar a sua "fidelidade" ao partido ou ao governo nas votações (pertencer ou não à base de apoio ao governo no Legislativo). Portanto, é necessário verificar se a proposta sofrerá diferentes impactos quando o governo também tem interesse nela, ou seja, se o parlamentar tende a ter um posicionamento diferente diante da agenda da indústria quando existe a necessidade de apoiar o governo em um posicionamento contrário.

Para contabilizar quem atuou pró ou contra o governo, levou-se em conta a filiação partidária do deputado à época de sua eleição, uma vez que o objetivo é analisar o comportamento em consonância com a agremiação à qual o parlamentar estava filiado quando recebeu o financiamento por parte da indústria. Com isso, 
classificou-se enquanto governo ou oposição o fato de seu partido ter feito parte da base de apoio ao primeiro mandato da presidente Dilma Rousseff (2011-2014), coincidente com o recorte temporal em estudo, com base nos dados extraídos da Radiografia do Novo Congresso, publicação do Departamento Intersindical de Assessoria Parlamentar (Diap) ${ }^{38}$ e endossados com os dados do Basômetro ${ }^{39}$ (Estadão).

\section{Categoria 5 - Pertence ou não à Frente Parlamentar da Indústria:}

$\mathrm{O}$ advento das bancadas suprapartidárias na Câmara dos Deputados, também reconhecidas como frentes parlamentares, remonta ao período imediatamente anterior ao governo militar no Brasil. Porém, somente foram reconhecidas sob tal denominação na 52 ${ }^{\mathrm{a}}$ legislatura (SIMIONATTO; COSTA, 2012 apud MACHADO, 2013).

Justamente por terem o caráter suprapartidário, ou seja, que está além das fronteiras de legenda, as frentes parlamentares reforçam o argumento de que a agenda legislativa não está integralmente sob o controle das lideranças partidárias, mas que existem temas pujantes na sociedade que podem vir a ganhar força dentro do parlamento, por intermédio desses grupos e, deste modo, pautar a dinâmica legislativa (ARAÚJO; SILVA; TESTA, 2015). De acordo com os mesmos autores:

As frentes e bancadas parlamentares temáticas são constituídas para atuar em diversos assuntos e apresentam realidades muito distintas quanto ao grau de organização. $O$ desafio que se coloca é compreender os processos e mecanismos associados às situações em que esses grupos tornam-se atores políticos relevantes nas decisões do Congresso Nacional.

\footnotetext{
${ }^{38}$ O Diap estimou a base de apoio do primeiro mandato da presidente Dilma Rousseff, levando em conta os partidos que compuseram a base aliada do segundo mandato do presidente Lula, seu antecessor. Classificam os partidos enquanto "Apoio Consistente", partidos que inegavelmente farão parte da base de apoio ao governo; "Apoio Condicionado", partidos com grande chance de fazer parte base de apoio ao governo; e "Oposição", os que não entrarão na base de apoio.

${ }^{39}$ Ferramenta interativa online, elaborada pelo jornal "Estadão", que tem por objetivo aferir o apoio de parlamentares e partidos ao governo em uma dada proposição, a partir de dados obtidos dos sites da Câmara dos Deputados e do Senado Federal. Na presente análise, utilizou-se a referida ferramenta como maneira de aferir se o apoio de determinado partido ao governo sofreu muitas oscilações do início ao fim da legislatura.
} 
O Regimento Interno da Câmara dos Deputados (RICD), por sua vez, não impede $^{40}$ a existência de frentes parlamentares informais, dada a relevância da atuação das frentes, principalmente na representação de demandas sociais. De acordo com o sítio da Câmara dos Deputados, a 54 ${ }^{\mathrm{a}}$ legislatura contou com a atuação de 212 frentes parlamentares $^{41}$, tanto formais, quanto informais.

As frentes parlamentares que representam os interesses da indústria, portanto, são bastante diversificadas. Não existe uma frente parlamentar que unifique o segmento industrial, mas sim frentes que identificam os diferentes segmentos industriais, que também são representados pela CNI. Na 54ª legislatura (2011-2014), foi possível identificar ao menos dezenove frentes diferentes, que envolvem os diferentes setores e segmentos da cadeia produtiva:

Quadro 2 - Frentes parlamentares do segmento industrial (54ª legislatura)

\begin{tabular}{|c|c|c|}
\hline Nome da frente & $\begin{array}{c}\text { Data de publicação no } \\
\text { DCD (Diário da Câmara } \\
\text { dos Deputados) }\end{array}$ & Coordenador/Presidente \\
\hline $\begin{array}{c}\text { Frente Parlamentar Mista } \\
\text { em Defesa do Complexo } \\
\text { Industrial da Saúde }\end{array}$ & $13 / 08 / 2014$ & Francisco Chagas \\
\hline $\begin{array}{c}\text { Frente Parlamentar do } \\
\text { Congresso Nacional de } \\
\text { apoio aos Produtores de } \\
\text { Algodão e as Indústrias do } \\
\text { Segmento }\end{array}$ & $28 / 06 / 2013$ & Sérgio Brito \\
\hline $\begin{array}{c}\text { Frente Parlamentar em } \\
\text { Defesa da Indústria } \\
\text { Brasileira de Bebidas }\end{array}$ & $12 / 08 / 2013$ & Zeca Dirceu \\
\hline $\begin{array}{c}\text { Frente Parlamentar Mista } \\
\text { em Defesa da Indústria } \\
\text { Marítima Brasileira }\end{array}$ & $17 / 07 / 2013$ & Edson Santos \\
\hline \begin{tabular}{c} 
Frente Parlamentar pela \\
\hline
\end{tabular} & $11 / 11 / 2013$ & Arnaldo Jardim \\
\hline
\end{tabular}

${ }^{40}$ Apesar de o RICD não impedir, não faz menção a esses grupos. Eles não têm atribuição regimental, mesmo sendo registrados na Câmara. Há, também, grupos que não se registram. Diferenciam-se entre frentes parlamentares (registradas, mesmo sem atribuições regimentais) e bancadas temáticas informais (não registradas como frentes) (ARAÚJO; SILVA; TESTA, 2015).

${ }^{41}$ Fonte: Sistema de registro da Câmara dos Deputados. http://www.camara.gov.br/internet/deputado/frentes.asp?leg=54. Acesso em 17/01/2016. 


\begin{tabular}{|c|c|c|}
\hline $\begin{array}{l}\text { Valorização do Setor } \\
\text { Sucroenergético }\end{array}$ & & \\
\hline $\begin{array}{l}\text { Frente Parlamentar pela } \\
\text { Valorização e Incentivo à } \\
\text { Mandiocultura. }\end{array}$ & $11 / 12 / 2013$ & Amauri Teixeira \\
\hline $\begin{array}{c}\text { Frente Parlamentar pelo } \\
\text { Desenvolvimento da } \\
\text { Apicultura e Cajucultura - } \\
\text { FPDAC }\end{array}$ & 05/08/2013 & Assis Carvalho \\
\hline $\begin{array}{l}\text { Frente Parlamentar do } \\
\text { Jovem Empreendedor }\end{array}$ & $27 / 08 / 2012$ & Hugo Motta \\
\hline $\begin{array}{c}\text { Frente Parlamentar em } \\
\text { Defesa da Competitividade } \\
\text { da Cadeia Produtiva do } \\
\text { Setor Químico, } \\
\text { Petroquímico e Plástico do } \\
\text { Brasil }\end{array}$ & $22 / 05 / 2012$ & Vanderlei Siraque \\
\hline $\begin{array}{c}\text { Frente Parlamentar em } \\
\text { Defesa da Indústria } \\
\text { Nacional }\end{array}$ & $22 / 05 / 2012$ & Newton Lima \\
\hline $\begin{array}{c}\text { Frente Parlamentar Mista } \\
\text { da Suinocultura }\end{array}$ & $16 / 07 / 2012$ & Vilson Covatti \\
\hline $\begin{array}{l}\text { Frente Parlamentar em } \\
\text { Defesa da Cadeia do Aço, } \\
\text { Ferro Gusa, Ferro Ligas, } \\
\text { Silício Metálico, seus } \\
\text { insumos e derivados. }\end{array}$ & 09/08/2011 & $\begin{array}{l}\text { Bernardo Santana de } \\
\text { Vasconcellos }\end{array}$ \\
\hline $\begin{array}{l}\text { Frente Parlamentar em } \\
\text { Defesa da Indústria } \\
\text { Aeronáutica Brasileira }\end{array}$ & 06/07/2011 & Júlio César \\
\hline $\begin{array}{c}\text { Frente Parlamentar em } \\
\text { Defesa dos Setores } \\
\text { Coureiro-Calçadista e } \\
\text { Moveleiro. }\end{array}$ & $23 / 05 / 2011$ & Renato Molling \\
\hline $\begin{array}{c}\text { Frente Parlamentar Mista } \\
\text { da Micro e Pequena } \\
\text { Empresa }\end{array}$ & $22 / 03 / 2011$ & Guilherme Campos \\
\hline $\begin{array}{l}\text { Frente Parlamentar Mista } \\
\text { em Defesa da Cafeicultura }\end{array}$ & $11 / 05 / 2011$ & Diego Andrade \\
\hline
\end{tabular}




\begin{tabular}{|c|c|c|}
\hline $\begin{array}{c}\text { Frente Parlamentar Mista } \\
\text { em Defesa do Segmento de } \\
\text { Hortifrutiflorigranjeiros }\end{array}$ & 22/07/2011 & Junji Abe \\
\hline $\begin{array}{c}\text { Frente Parlamentar Mista } \\
\text { José Alencar para o } \\
\text { Desenvolvimento da } \\
\text { Indústria Têxtil e da } \\
\text { Confecção do Brasil }\end{array}$ & $02 / 09 / 2011$ & Zeca Dirceu \\
\hline
\end{tabular}

Fonte: Elaboração própria, com base nos dados extraídos do sítio da Câmara dos Deputados.

Nessa seleção, levou-se em conta o que o Diap já sinalizava: muitos deputados que se declaram como empresários são do ramo agropecuário, apesar de muitos também se declararem como pecuaristas. Embora tenha essa distinção e, ao mesmo tempo, as pautas serem as mesmas, não existe um diálogo entre as frentes da indústria e a bancada ruralista, uma das que possui maior atividade e influência na Câmara dos Deputados (MACHADO, 2013). Também nota-se que há incidência sempre dos mesmos deputados nas diferentes frentes. Essa distorção decorre do fato de a Mesa da Câmara exigir 1/3 das assinaturas para registrar a frente. Porém, para os fins a que essa análise se destina, a Frente Parlamentar em Defesa da Indústria Nacional foi a frente escolhida como referência para filtrar os parlamentares que atuam pró-indústria na Câmara dos Deputados, por ser a agremiação que não adota uma vertente setorial especifica, sendo de cunho mais generalístico, entre as frentes em atuação na legislatura em estudo.

Essa diversidade de frentes parlamentares também se reflete nos diferentes temas das proposições prioritárias das Pautas Mínimas, que conseguem contemplar a extensa e divergente pauta da indústria em grandes temas. A classificação da Tabela 12 foi elaborada pela própria CNI, na categorização das proposições nas Pautas Mínimas.

Tabela 12 - Temas que figuram nas proposições das Pautas Mínimas (2011-2014)

\begin{tabular}{|c|c|}
\hline Área temática & Número de ocorrências \\
\hline Direito de propriedade e contratos & 1 \\
\hline Gasto público & 1 \\
\hline Infraestrutura & 9 \\
\hline Legislação trabalhista & 5 \\
\hline
\end{tabular}




\begin{tabular}{|c|c|}
\hline Meio-ambiente & 7 \\
\hline Micro e pequenas empresas & 1 \\
\hline Política econômica & 2 \\
\hline Questão institucional & 5 \\
\hline Regulamentação da economia & 7 \\
\hline Relações de trabalho & 2 \\
\hline Sistema tributário & 13 \\
\hline Total & $\mathbf{5 3}$ \\
\hline
\end{tabular}

Fonte: Elaboração própria, com dados extraídos das Pautas Mínimas da CNI.

\section{Categorias 6 e 7: Autoria ou relatoria de proposições e Cargos na Mesa Diretora, em Comissão ou Liderança partidária:}

Segundo Inácio, "O poder de agenda refere-se à capacidade de determinado autor influenciar ou determinar as alternativas consideradas nos processos decisórios, em relação ao conteúdo e aos procedimentos a partir dos quais tais alternativas se convertem em decisões políticas" (FIGUEIREDO; LIMONGI, 1999; COX, 2003 apud INÁCIO, 2007).

Em se tratando de Câmara dos Deputados, existem alguns atores que, de acordo com as prerrogativas regimentais, influenciam diretamente e de maneira privilegiada o processo legislativo, seja no âmbito das comissões, em plenário ou para decidir a agenda da Casa: o presidente da Câmara e os secretários da Mesa Diretora; os presidentes de comissões; os líderes partidários e do governo; e os autores e relatores de proposições. Por conta disso, tais atores foram selecionados para compor as categorias de comportamento, visto que possuem poder de agenda, de veto e de influência no resultado final de uma dada matéria (AGUIAR, 2013).

Embora este termo seja comumente utilizado pela literatura para se referir à influência do Executivo no Legislativo, o poder de agenda, segundo Powell (2005) apud Aguiar (2013): 
[...] é uma forma de avaliar o grau de accountability vertical, isto é, o comportamento dos parlamentares em relação à representação e ao cumprimento dos interesses de seus eleitores. Assim, se um parlamentar influencia pouco na definição da agenda, isso implica que terá pouca oportunidade de dar voz aos interesses de seus eleitores ${ }^{42}$, o que leva a uma ruptura no processo de representação, tanto de interesses quanto de opiniões e perspectivas.

O poder de veto, por sua vez, determina que uma decisão só se concretizará quando estes atores-chave, ou veto players, estiverem em concordância ou optarem pela não decisão. Já o poder de influência destes atores, papel mais nitidamente observável na figura das lideranças partidárias, se refere à capacidade de convencer os demais atores em agirem de uma determinada forma ou a tomarem certa decisão.

Por terem poderes regimentalmente assegurados, os atores listados são peçachave do processo legislativo. Consequentemente, são comumente os mais procurados por lobistas e grupos de interesse, por estarem institucionalmente centralizados e pelo seu grau de influência na tomada de decisões.

Com a inclusão de tais categorias na análise, pretende-se aferir se o financiamento de origem industrial destinado a tais atores, isoladamente, faz com que o parlamentar acompanhe o posicionamento do segmento em sua tomada de decisões.

\section{Tabela 13 - Número de parlamentares financiados pela indústria que são atores- chave no processo legislativo}

\begin{tabular}{|c|c|}
\hline Atribuição & Quantitativo \\
\hline Autor ou relator & 9 \\
\hline $\begin{array}{c}\text { Cargo na Mesa Diretora, Presidência de } \\
\text { Comissão ou Liderança partidária }\end{array}$ & 39 \\
\hline Total & $\mathbf{4 6}$ \\
\hline
\end{tabular}

Fonte: Elaboração própria.

Dos 239 parlamentares em estudo, apenas 46 destes possui alguma das atribuições regimentais-chave que foi elencada para as categorias 6 e 7, o que equivale a

\footnotetext{
${ }^{42}$ Para o presente caso, dar voz aos interesses de seus financiadores de campanha.
} 
$19 \%$ do total, aproximadamente. Não é de se espantar que o número é baixo, apesar de alto para a presente amostra, tendo em vista o alto grau de centralização institucional da participação e da decisão na mão destes atores (SANTOS, 2010). Observou-se, portanto, que nenhum dos que configuraram enquanto autores ou relatores de proposição ocupavam, concomitantemente, algum dos cargos mencionados.

A Tabela 14 mostra que, apesar da importância do papel desempenhado pelo o presidente da Câmara e os secretários da Mesa Diretora; os presidentes de comissões; os líderes partidários e do governo e os autores e relatores de proposições, o financiamento destinado a estes atores não é proporcional à sua relevância no processo decisório.

Tabela 14 - Montante do financiamento de origem industrial dos atores-chave, em ordem decrescente de valores

\begin{tabular}{|c|c|}
\hline Parlamentares & Montante do financiamento \\
\hline Arlindo Chinaglia & $\mathrm{R} \$ 2.971 .459,38$ \\
\hline Eduardo Azeredo & $\mathrm{R} \$ 1.569 .754,80$ \\
\hline Antonio Balhmann & $\mathrm{R} \$ 1.375 .400,92$ \\
\hline Weliton Prado & $\mathrm{R} \$ 1.052 .838,70$ \\
\hline Leonardo Quintão & $\mathrm{R} \$ 1.027 .382,39$ \\
\hline Jilmar Tatto & $\mathrm{R} \$ 996.347,93$ \\
\hline Bruno Araújo & $\mathrm{R} \$ 920.000,00$ \\
\hline Newton Lima & $\mathrm{R} \$ 894.308,27$ \\
\hline Pedro Eugênio & $\mathrm{R} \$ 763.500,00$ \\
\hline Augusto Coutinho & $\mathrm{R} \$ 722.500,00$ \\
\hline Vitor Penido & $\mathrm{R} \$ 631.135,00$ \\
\hline Giovani Cherini & $\mathrm{R} \$ 532.660,74$ \\
\hline Jorge Boeira & $\mathrm{R} \$ 501.870,00$ \\
\hline Cesar Colnago & $\mathrm{R} \$ 496.570,00$ \\
\hline Oziel Oliveira & $\mathrm{R} \$ 478.282,70$ \\
\hline
\end{tabular}




\begin{tabular}{|c|c|}
\hline Cláudio Puty & $\mathrm{R} \$ 456.055,00$ \\
\hline Fernando Francischini & $\mathrm{R} \$ 448.620,93$ \\
\hline Ricardo Izar & $\mathrm{R} \$ 446.313,32$ \\
\hline Washington Reis & $\mathrm{R} \$ 415.131,04$ \\
\hline André Vargas & $\mathrm{R} \$ 349.468,40$ \\
\hline Júlio Cesar & $\mathrm{R} \$ 345.610,31$ \\
\hline Arthur Oliveira Maia & $\mathrm{R} \$ 342.148,39$ \\
\hline Padre João & $\mathrm{R} \$ 311.540,00$ \\
\hline Carlos Eduardo Cadoca & $\mathrm{R} \$ 273.000,00$ \\
\hline Alessandro Molon & $\mathrm{R} \$ 272.600,00$ \\
\hline Simão Sessim & $\mathrm{R} \$ 247.172,19$ \\
\hline Antônio Imbassahy & $\mathrm{R} \$ 242.482,88$ \\
\hline Biffi & $\mathrm{R} \$ 211.330,00$ \\
\hline Celso Maldaner & $\mathrm{R} \$ 192.248,30$ \\
\hline Alice Portugal & $\mathrm{R} \$ 139.600,00$ \\
\hline Inocêncio Oliveira & $\mathrm{R} \$ 100.000,00$ \\
\hline Assis Carvalho & $\mathrm{R} \$ 96.381,52$ \\
\hline Dr. Grilo & $\mathrm{R} \$ 70.000,00$ \\
\hline Marco Maia & $\mathrm{R} \$ 52.980,00$ \\
\hline Renan Filho & $\mathrm{R} \$ 32.250,00$ \\
\hline Henrique Eduardo Alves & $\mathrm{R} \$ 30.000,00$ \\
\hline César Halum & $\mathrm{R} \$ 20.000,00$ \\
\hline Roberto Britto & $\mathrm{R} \$ 18.600,91$ \\
\hline Fátima Bezerra & $\mathrm{R} \$ 15.000,00$ \\
\hline Otavio Leite & $\mathrm{R} \$ 10.000,00$ \\
\hline Manuela D'Ávila & $\mathrm{R} \$ 7.150,00$ \\
\hline
\end{tabular}




\begin{tabular}{|c|c|}
\hline Domingos Dutra & $\mathrm{R} \$ 4.100,00$ \\
\hline Dr. Paulo César & $\mathrm{R} \$ 4.100,00$ \\
\hline João Arruda & $\mathrm{R} \$ 1.000,00$ \\
\hline Júlio Delgado & $\mathrm{R} \$ 1.000,00$ \\
\hline Jorge Bittar & $\mathrm{R} \$ 970,50$ \\
\hline Gabriel Guimarães & $\mathrm{R} \$ 0,00^{43}$ \\
\hline Vitor Paulo & $\mathrm{R} \$ 0,00^{44}$ \\
\hline TOTAL & $\mathbf{R} \$ \mathbf{2 0 . 0 9 0 . 8 6 4 , 5 2}$ \\
\hline
\end{tabular}

Fonte: Elaboração própria.

Quem encabeça a lista, somando os maiores valores do financiamento de origem empresarial, é o deputado Arlindo Chinaglia (PT/SP), que exerceu a função de $1^{\text {o }}$ vice-presidente da Mesa Diretora durante o ano de 2014, além de ter sido escolhido como líder do governo na Câmara no ano de 2012, duas posições de extrema relevância e centralidade.

\section{Categoria 8: Parlamentar é Novato ou Veterano}

O financiamento de campanha concedido a um parlamentar pode não representar apenas mera doação, mas também recompensa pelo seu comportamento passado. Na questão do financiamento, é importante olhar para o futuro (esperando um comportamento responsivo) e também para o histórico do parlamentar (como ele agiu em legislaturas passadas, que justificaria um novo financiamento). No caso da presente pesquisa, o enfoque será dado no comportamento esperado do parlamentar, porém, levando em conta sua atuação junto às proposições prioritárias da indústria.

Os dados apontam em uma direção de um comportamento já sinalizado por Pereira e Rennó (2007), em estudo sobre os determinantes do sucesso eleitoral dos reeleitos nas eleições de 1998 e 2002 para a Câmara dos Deputados. Dos 239 parlamentares do presente estudo, $143(61,5 \%)$ destes foram reeleitos, conta $92(38,4 \%)$ que estavam em seu primeiro mandato. Segundo os autores citados, "a decisão pela ambição estática, ou seja, concorrer à reeleição, tem consistentemente proporcionado

${ }^{43} \mathrm{O}$ deputado Vitor Paulo (PRB/RJ), não recebeu financiamento de pessoa jurídica em sua campanha, além de repasses do comitê financeiro.

${ }^{44}$ A prestação de contas do deputado Gabriel Guimarães não se encontram disponíveis no sítio do TSE. 
retornos eleitorais para a maioria dos parlamentares que a tentam" (PEREIRA; RENNÓ, 2007).

Recuperando o debate do Capítulo 2 sobre os incumbents (candidatos detentores de cargos) e aos challengers (candidatos que não possuem cargo), no tocante à diferença no montante dos gastos e a sua influência nos outputs eleitorais, oriundo da literatura norteamericana, pretende-se verificar, com a adoção desta categoria, se o fato de o parlamentar já ser conhecido (veterano) por atuar em consonância com a indústria influencia o fato de ele ser reeleito, juntamente com a influência das demais variáveis do estudo.

\section{Categoria 9: Existência de interesse do Executivo na proposição}

Como já abordado na Seção 3.3, a categoria de comportamento selecionada pretende abordar o contrafactual, ou seja, a quem respondem os parlamentares quando o interesse do governo também está em jogo, além do interesse do empresariado industrial, conforme sinalizado pela CNI nas proposições da Pauta Mínima. Em todas as oito proposições selecionadas, o Executivo sinalizou interesse, seja pela matéria ter sido de sua iniciativa, exclusiva ou não, ou pela relevância direta da temática para o governo.

\section{3 - Resultados e discussão}

A aplicação metodológica realizada através do uso da QCA se dá por meio da seleção de um objeto, cuja análise pode ser entendida por meio da teoria dos conjuntos (no presente caso, ausência ou presença/sim ou não, onde a ausência ou a negação da condição é representada pelo sinal gráfico “ ”, como exemplificado na Figura 1), mostrando que, a partir das combinações das variáveis ou casos em estudo, é possível se obter diferentes explicações para um mesmo outcome.

Os resultados obtidos através do software fs/QCA 2.5, utilizado para rodar os dados, estão demonstrados na Figura 1. A partir dela, é possível observar que o software reportou um total de doze configurações (representadas pelas linhas, que exibem a combinação das variáveis de um determinado arranjo). Dependendo da forma como se combinam, podem apresentar diferentes respostas para um mesmo fenômeno. Deste total, somente oito foram levadas em conta para a presente análise. Os demais casos, reportados enquanto espúrios, serão tratados no Subcapítulo 5.3.1. 


\section{Figura 1 - Output gerado pelo crisp-set QCA}

\begin{tabular}{|c|c|c|c|}
\hline \multirow[t]{3}{*}{$\begin{array}{l}\text {-- INTERMEDIATE SOLUTION --- } \\
\text { Irequency cutoff : } 1.000000 \\
\text { consistency cutoff: } 0.666667 \\
\text { Assumptions: }\end{array}$} & \multirow{2}{*}{\multicolumn{2}{|c|}{$\begin{array}{l}\text { unique } \\
\text { coverage }\end{array}$}} & \multirow[b]{2}{*}{ consistency } \\
\hline & & & \\
\hline & 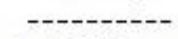 & 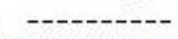 & 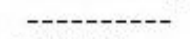 \\
\hline autorrelator $\star$ interesseexec*coalizão» $\sim$ industrempr & 0.655172 & 0.172414 & 0.798319 \\
\hline autorrelator interesseexec $^{\star} \sim$ ocupacargo $\sim$ veterano $* \sim$ industrempr & 0.020690 & 0.003448 & 1.000000 \\
\hline autorrelator ${ }^{\star} \sim$ ocupacargo $*$ veterano $* \sim$ pertencef rente ${ }^{\star}$ coalizão & 0.017241 & 0.013793 & 1.000000 \\
\hline interesseexec ${ }^{\star} \sim$ veterano $^{\star} \sim$ pertencef rente ${ }^{\star}$ coalizão ${ }^{\star} \sim$ industrempr & 0.213793 & 0.003448 & 0.826667 \\
\hline 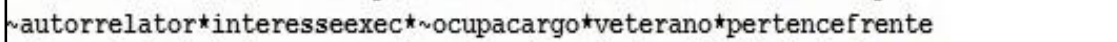 & 0.110345 & 0.003448 & 0.800000 \\
\hline 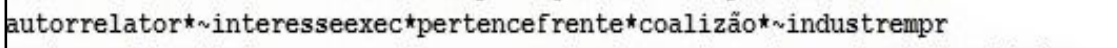 & 0.024138 & 0.024138 & 1.000000 \\
\hline 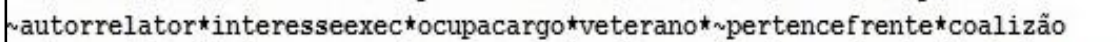 & 0.037931 & 0.003448 & 0.785714 \\
\hline 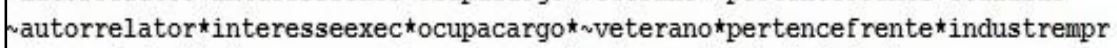 & 0.024138 & 0.013793 & 0.777778 \\
\hline autorrelator ${ }^{\star}$ interesseexec ${ }^{\star} \sim$ ocupacargo pertencef rente $^{\star} \sim$ indust $r e m p r$ & 0.031034 & -0.000000 & 1.000000 \\
\hline interesseexec $\sim_{\sim}$ ocupacargo veteranokpertencef rente $^{\star} \sim$ industrempr & 0.110345 & -0.000000 & 0.800000 \\
\hline autorrelator ${ }^{\star}$ interesseexec ${ }^{\star} \sim$ veterano ${ }^{\star}$ pertencef rente ${ }^{\star}$ coalizão & 0.196552 & -0.000000 & 0.730769 \\
\hline 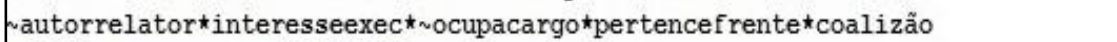 & 0.217241 & -0.000000 & 0.750000 \\
\hline solution coverage: 0.817241 & & & \\
\hline solution consistency: 0.817241 & & & \\
\hline
\end{tabular}

Fonte: Elaboração própria, gerado a partir do software fs/QCA 2.5.

O propósito do presente capítulo é mostrar em quais condições os parlamentares se comportam de acordo com o posicionamento sinalizado pela CNI para uma dada proposição. Em outras palavras, quais são as variáveis que explicam ou não influenciam no posicionamento de um parlamentar: quando analisadas em um contexto de multicausalidade, quais são as categorias de comportamento que impactam mais ou menos que a condição (outcome) "acompanhar o posicionamento da CNI", ou seja, do financiador de campanha, no posicionamento do parlamentar. A Tabela 15 traz a definição de cada categoria de comportamento utilizada na análise.

Tabela 15 - Categorias de comportamento

\begin{tabular}{|c|c|}
\hline Categoria & Legenda \\
\hline autorrelator & $\begin{array}{c}\text { O parlamentar é autor ou relator da } \\
\text { proposição (Categoria 6) }\end{array}$ \\
\hline coalizão & $\begin{array}{c}\text { O parlamentar faz parte da coalizão } \\
\text { governista (Categoria 4) }\end{array}$ \\
\hline industremp & O parlamentar é industrial ou empresário \\
\hline
\end{tabular}




\begin{tabular}{|c|c|}
\hline interesseexec & (Categoria 3) \\
\hline ocupacargo & $\begin{array}{c}\text { Existe interesse do Poder Executivo na } \\
\text { proposição (Categoria 9) }\end{array}$ \\
\hline pertencefrente & $\begin{array}{c}\text { O parlamentar ocupa cargos na Mesa, em } \\
\text { comissão ou de liderança (Categoria 7) }\end{array}$ \\
\hline veterano & $\begin{array}{c}\text { O parlamentar pertence à Frente } \\
\text { Parlamentar da Indústria (Categoria 5) }\end{array}$ \\
\hline O parlamentar é veterano ou não \\
(Categoria 8)
\end{tabular}

Fonte: Elaboração própria.

\section{Output 1:}

autorrelator*interesseexec*coalizão* industrempr

Raw Coverage: 0.655172 / Unique Coverage: 0.172414 / Consistency: $0.798319^{45}$

Para este output, é possível notar que apenas quatro das sete categorias de comportamento aparecem como relevantes (suficientes ou necessárias) para a explicação. No caso, o parlamentar não é autor ou relator de proposição, não é industrial ou empresário, é da coalizão governista e o Executivo sinalizou interesse na proposição. Vê-se, portanto, uma situação onde provavelmente o parlamentar votou apenas de acordo com os interesses ideológicos (por ser da coalizão governista), sem influência de fatores como se ele é veterano ou se ocupa algum cargo chave dentro do processo legislativo, apesar de ter acompanhado o interesse da CNI. Para um cutoff ${ }^{46}$ de 0.66 , a consistency é relativamente alta, bem como a unique coverage, que é a maior de todas, entre os casos reportados. Ou seja, existe um alto número de casos que são explicados por essa configuração em específico: onde o parlamentar meramente age por interesses ideológicos.

\footnotetext{
45 A Raw Coverage explica o percentual de explicação de cada configuração, enquanto a Unique Coverage abrange a proporção dos casos que são explicados exclusivamente pela dada configuração, ou seja, que não são cobertos por outras soluções. A Consistency, por sua vez, trata-se da consistência, da precisão de cada configuração, de acordo com os algoritmos booleanos (binários, 0 ou 1) do software para cada resultado esperado (RAGIN, 2008a; SILVA, 2013). Para fins de convenção, uma variável é considerada "suficiente" quando sua consistency for $>0.8$ e "necessária" quando for $>0.9$.

${ }^{46}$ Grau de consistency mínima, calibrado pelo pesquisador, para encontrar um dado conjunto de configurações (RAGIN, 2008a; SILVA, 2013).
} 


\section{Output 2:}

autorrelator*interesseexec* ${ }^{*}$ ocupacargo $*$ veterano* ${ }^{*}$ industrempr

Raw Coverage: 0.020690 / Unique Coverage: 0.003448 / Consistency: 1.000000

O output 2 indica que o parlamentar é autor ou relator da proposição, cujo Executivo sinalizou interesse, é novato, não ocupa cargo chave no processo decisório e não é industrial ou empresário. Trata-se, portanto, dos casos onde o parlamentar acompanhou a CNI por ser meramente autor ou relator da proposição, endossado pela consistência máxima (valor 1). São, porém, poucos os casos, tendo em vista a raw coverage baixa e a unique coverage, mais baixa ainda, explicado pelo pouco número de parlamentares que foram classificados enquanto autores ou relatores de proposição para este estudo.

\section{Output 3:}

autorrelator* ocupacargo $* \sim$ veterano* pertencefrente*coalizão

Raw Coverage: 0.017241 / Unique Coverage: 0.013793 / Consistency: 1.000000

Na situação do output 3, o parlamentar é autor ou relator da proposição, não ocupa cargo-chave no processo decisório dentro do Legislativo, é novato, não pertence à Frente Parlamentar da Indústria e é da coalizão governista. Excetuando a questão de ser um parlamentar novato, possivelmente um challenger, a situação se assemelha bastante à do output 2, principalmente por serem poucos os casos cobertos por essa configuração. $O$ fato de ser da coalizão, portanto, não influenciou substancialmente o resultado, tendo em vista que a adição desta categoria na análise reportou valores semelhantes aos do output 2 na raw coverage e muito próximos na unique coverage.

\section{Output 4:}

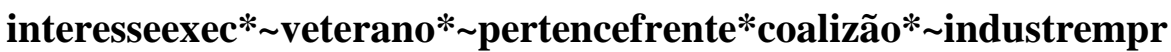

Raw Coverage: 0.213793 / Unique Coverage: 0.003448 / Consistency: 0.826667 
O output 4 traz uma configuração onde existe interesse do Executivo na proposição, o parlamentar em questão é novato, não pertence à Frente Parlamentar da Indústria, não é industrial ou empresário, mas é da coalizão. Diferentemente dos outputs 2 e 3, o parlamentar novato, em questão, pode não ser um challenger, tendo em vista que não preenche o perfil de ser do ramo empresarial ou industrial e não pertence à Frente. Trata-se de um parlamentar que é da base do governo no Legislativo e que acompanhou os ditames do Executivo para uma determinada proposição. A sinalização da CNI, nessa configuração, pode não ter tido tanta força, tendo em vista o background do parlamentar. Igualmente, são poucas as situações onde essa configuração é aplicável, por conta da unique coverage baixíssima.

\section{Output 5:}

autorrelator*interesseexec* ${ }^{*}$ ocupacargo*veterano*pertencefrente

Raw Coverage: 0.110345/ Unique Coverage: 0.003448 / Consistency: 0.800000

Reportando exatamente a unique coverage do output 4, o que já mostra se tratar de uma configuração com pouquíssimos casos, o output 5 trata de uma situação onde o Executivo sinalizou interesse na proposição, o parlamentar não é autor nem relator da mesma, não ocupa cargo-chave, é veterano e pertence à Frente Parlamentar da Indústria. Possivelmente, este é um caso de parlamentares incumbents, justamente por pertencerem à Frente, por serem veteranos e por não sofrerem influência da questão ideológica (pertencerem ou não à coalizão governista, tendo em vista que a categoria não apareceu na configuração), perfil que se enquadra no interesse dos financiadores que buscam contribuir para a campanha de parlamentares que já possuem mandato e alguma afinidade com a temática da indústria (no caso, serem da Frente ou já serem do ramo, categoria que não foi reportada).

\section{Output 6:}

autorrelator* ${ }^{*}$ interesseexec*pertencefrente*coalizão* industrempr

Raw Coverage: 0.024138 / Unique Coverage: 0.024138 / Consistency: 1.000000 
Para o output 6, a configuração reportou que o parlamentar é autor ou relator da proposição, cujo interesse do Executivo é inexistente. Apesar disso, o parlamentar faz parte da base de sustentação do governo no Legislativo, não preenche o perfil de ser industrial ou empresário, mas pertence à Frente Parlamentar da Indústria. Ou seja, é um caso de provável simpatizante dos interesses da indústria, apesar de não ser do ramo. $\mathrm{O}$ parlamentar ser autor ou relator da proposição faz com que o fato de ele ser da coalizão governista, embora não exista o interesse do Executivo na proposição, acabe por se tornar uma categoria que pouco tem peso em sua decisão de acompanhar ou não a CNI, uma vez que o interesse que tá em jogo é seu posicionamento pessoal naquela proposição, influenciado ou não pela orientação da indústria, uma vez que ele pode ser um ator-chave dentro desse processo, no caso de se tratar de um relator.

\section{Output 7:}

autorrelator*interesseexec* ocupacargo*veterano* ${ }^{*} \sim$ pertencefrente*coalizão

Raw Coverage: 0.037931 / Unique Coverage: 0.003448 / Consistency: 0.785714

Embora se trate de uma configuração com uma unique coverage baixa, o output 7 é um dos únicos casos em que apareceram quase todas as categorias de comportamento em estudo. Nesta configuração, existe o interesse do governo na proposição, o parlamentar faz parte da base de apoio ao governo, não é autor ou relator, ocupa cargo-chave no processo decisório no Legislativo, é veterano e não é da Frente Parlamentar da Indústria. Possivelmente, mais um caso de challenger, uma vez que, pelo perfil reportado, aparentemente é um parlamentar com mais de dois mandatos (não está em sua segunda legislatura), por assumir cargos relevantes e não ter ligações suprapartidárias, como pertencimento à Frente, apesar de ser da coalizão governista. Pelos valores reportados pelas coverages, trata-se de um caso excepcional, ou seja, que explica poucos casos, entre as configurações reportadas. 


\section{Output 8:}

autorrelator*interesseexec*ocupacargo* ${ }^{*}$ veterano*pertencefrente*industrempr

Raw Coverage: 0.024138 / Unique Coverage: 0.013793 / Consistency: 0.777778

Reportando 6 das 7 categorias de comportamento em análise, o output 8 explora um parlamentar que, embora não seja autor ou relator de proposição, possui cargo-chave no Legislativo, pertence à Frente Parlamentar da Indústria, é novato e do ramo empresarial. Além disso, o Executivo sinalizou interesse na proposição, apesar de a análise não ter reportado se o parlamentar é da base do governo ou não, categoria que, provavelmente, não influencia na configuração. É bastante semelhante ao output 7 , excetuando o fato de que, nesta análise, o parlamentar, além de ser do ramo, pertence à Frente, o que em princípio indica ser um parlamentar atuante na causa da indústria e, por conta disso, atrativo aos olhos dos financiadores.

Pelo perfil reportado, embora tenha grandes chances de se tratar de um challenger que avocou a pauta da indústria, provavelmente por ter recebido financiamento de origem empresarial, é um caso claro de parlamentar que se comporta conforme os ditames do segmento industrial, uma vez que inexiste o quesito ideológico (fazer parte da coalizão governista) como fator interveniente, o que acaba por suplantar o fato de o Executivo ter sinalizado interesse na proposição.

\subsection{1 - Configurações: casos espúrios}

O termo "espúrio", no presente contexto, foi utilizado para referenciar os casos que foram reportados no output, porém, que não são de relevância para os fins a que esta análise se dedica. A unique coverage indica o nível de cobertura que determinada linha de configuração representa na solução, excluindo-se as demais linhas. Ou seja, é a cobertura isolada da linha de configuração. De acordo com o resultado reportado para tais configurações nas uniques coverages, pode-se concluir que esta linha de configuração representa, na verdade, um subconjunto de outras soluções. Em outras palavras, ela está abarcada por outras soluções.

Tal aspecto, portanto, não é muito bem tratado pela literatura de QCA. É algo que somente precisa ser ressaltado quando é bastante representativo, ou seja, quando 
está acima de 0.1000000 , pois indicaria uma grande predominância destas, em termos de cobertura em relação às demais configurações. O mais importante é a leitura da unique coverage em conjunto com a consistency e com a raw coverage. Se a consistency ficar muito próxima a 0.75 e a raw coverage ficar abaixo de 0.100000 , possivelmente a linha de configuração não seja muito explicativa, a ponto de ser destacada em relação às demais.

A partir da Figura 1, é possível observar que quatro configurações reportaram, para as uniques coverages, valores de “-0.000000”, embora apresentem valores normais para a raw coverage, bem como para a consistency. Tendo em vista que as condições selecionadas para a análise são correlacionadas e que a unique coverage supõe a relevância de uma configuração dentro do universo observável, indicando que parte do resultado é explicada exclusivamente por um determinado caminho alternativo (RAGIN, 2006; SCHNEIDER; WAGEMANN, 2007 apud SCHNEIDER; WAGEMANN, 2010), por ter reportado um valor nulo, acompanhado do sinal aritmético de subtração, as configurações, abaixo elencadas, não serão tomadas em consideração para o presente estudo, uma vez que as condições não foram suficientes para explicar o outcome:

We call cases uniquely covered if they are a member of only one path of the solution. Cases with simultaneous presence of multiple paths are inadequate for within-case analysis because one should focus on a single path and how it leads to the outcome (GEORGE; BENNETT, 2005 apud SCHNEIDER; ROHLFING, 2013).

\section{Configuração espúria 1:}

autorrelator*interesseexec ${ }^{*} \sim$ ocupacargo* pertencefrente* ${ }^{*}$ industrempr:

O parlamentar é autor ou relator da proposição, cujo Executivo sinalizou interesse. Não ocupa nenhum cargo na Mesa, em comissão ou de liderança, pertence à Frente Parlamentar da Indústria, mas não é do ramo.

\section{Configuração espúria 2:}

interesseexec* ${ }^{*}$ ocupacargo*${ }^{*}$ veterano*pertencefrente* ${ }^{*}$ industrempr: 
O parlamentar não ocupa cargo-chave no processo decisório, é veterano, pertence à Frente Parlamentar da Indústria, porém, não é industrial ou empresário. Além disso, o Executivo sinalizou interesse na proposição.

\section{Configurações espúrias 3 e 4:}

autorrelator*interesseexec* $\sim$ veterano* pertencefrente*coalizão

autorrelator*interesseexec* ${ }^{*}$ ocupacargo*pertencefrente*coalizão:

Em ambas as categorias, o parlamentar não é autor ou relator da proposição, pertence à Frente Parlamentar da Indústria e também à coalizão governista na Câmara, além de existir interesse do governo na proposição. $O$ que diferencia as duas configurações, porém, é o fato de o parlamentar ser novato, em uma, e de não ocupar cargo-chave, em outra, o que fez com que a raw coverage das categorias se diferenciasse minimamente, em termos de valores $(0.196552$ e 0.217241 , respectivamente).

\subsection{2 - Comentários gerais sobre os resultados}

Apesar de ter reportado os casos espúrios, que apresentam as condições que são necessárias para explicar o outcome, porém, não suficientes, a adoção do método comparativo se mostrou bastante eficaz para mostrar o quanto cada categoria pode explicar do comportamento parlamentar, dependendo do arranjo configuracional em que se encontrar. Em outras palavras, mais que condições individuais, o comportamento parlamentar é sempre resultado de uma confluência de fatores e deve ser entendido dentro das combinações das condições, que produzem o outcome observado (FREITAS; BIZZARRO NETO, 2014). Trata-se, portanto, de um método que traz para a análise maiores traços de fidedignidade com o objeto de estudo, viabilizada pela síntese qualiquanti.

Assim como pretendido, a análise dos outputs mostrou que, dependendo do arranjo configuracional estabelecido, estas podem imprimir diferentes pesos às variáveis. Em outras palavras, uma variável que, em um determinado contexto, pode-se assumir como de extrema relevância, quando combinada com um diferente arranjo de variáveis, pode não assumir um papel de destaque ou, simplesmente, não aparecer na 
configuração. Tal fato confirma a importância do uso da QCA para o tipo de estudo pretendido, por fazer com que a análise empírica destaque as nuances e a multivariedade do comportamento parlamentar, tal como ocorre na prática.

Verificou-se, portanto, que o fato do parlamentar estar ou não em consonância com os anseios da CNI independe, muitas vezes, do fator ideológico (ser ou não da base governista), tendo em vista que, por ser da coalizão e tendo o governo sinalizado interesse na proposição, o parlamentar tende a acompanhar seu posicionamento. Por outro lado, acompanhar a sinalização da CNI para uma dada proposição depende, em grande parte das vezes, da predisposição do parlamentar para tal.

Observou-se, também, que os parlamentares que recorrentemente atuaram em diferentes proposições da CNI não necessariamente atuavam sempre no sentido de convergir com o posicionamento da indústria. Por outro lado, em vários dos posicionamentos, a referência ao interesse da CNI foi fator crucial para que os deputados se posicionassem, cabendo até mesmo menção explícita em alguns dos discursos analisados para este estudo.

Variáveis que comumente são exploradas isoladamente, como a importância do parlamentar assumir postos-chave dentro do processo legislativo, enquanto autor, relator ou ocupar cargos na Mesa ou em comissão; o peso do papel do Executivo nas decisões legislativas; e a importância de se fazer parte da coalizão governista para auferir ganhos legislativos, se mostraram harmonicamente em consonância com variáveis menos exploradas, como o fato de o deputado ser veterano ou novato; a relevância de se pertencer ou não a uma frente parlamentar; e se o seu perfil, ou background, necessariamente irá influenciar em sua conduta legislativa.

Os resultados mostram, em suma, que o financiamento de campanhas exerce, sem dúvidas, um peso considerável no comportamento do parlamentar, embora, muitas vezes, este não faça questão de deixar clara tal influência, principalmente nos discursos parlamentares. Porém, devido à complexidade da dinâmica parlamentar, vários fatores, quando em confluência, podem influenciar no posicionamento de um determinado deputado, para além do dinheiro. Eis a importância da análise sob a égide da multicausalidade. 


\section{6 - CONSIDERAÇÕES FINAIS}

O presente estudo pretendeu investigar em que medida o financiamento de campanhas, aos moldes da legislação eleitoral brasileira vigente, é capaz de influenciar o comportamento dos deputados federais agraciados pelas contribuições eleitorais de origem industrial. Tendo em vista a complexidade do processo legislativo e os múltiplos fatores que circundam a atividade parlamentar, buscou-se, através do método comparativo e da análise multicausal, aferir quais os determinantes, para além do financiamento de campanhas, que imprimem ou não impacto, quando analisados conjuntamente, ao fato de o parlamentar seguir a orientação da CNI para uma dada proposição.

Os resultados (outcomes) das análises confirmam, em larga medida, as expectativas delineadas por este estudo: o financiamento eleitoral empresarial, além de favorecer fortemente o desempenho eleitoral dos candidatos, é mais bem explicado quando analisado sob a égide de múltiplos fatores (MANCUSO; SPECK, 2015). Assim como no cenário pré-eleitoral, a lógica se repete quando o objeto de estudo se transmuta para o contexto pós-eleitoral: a análise do comportamento parlamentar não pode ser desvencilhada da experiência dinâmica que é o processo legislativo, onde existe uma multiplicidade de fatores intervenientes que, se analisados de forma agregada e sob a lógica da multicausalidade, explicam, de uma maneira mais verossímil, do que a análise isolada de uma determinada variável dependente.

Acompanhar o posicionamento da indústria em uma determinada proposição é, de certa maneira, uma espécie de comportamento que não depende fundamentalmente do fator ideológico (pertencer ou não à base do governo), mas da predisposição do parlamentar para fazê-lo, como reportado por alguns dos outputs analisados. Por outro lado, por fazer parte da coalizão governista no Legislativo, os parlamentares tendem a acompanhar o Executivo, nas matérias que este sinaliza interesse, embora no período em estudo (2011-2014), como mostrado alhures nesta dissertação, o governo foi parceiro da indústria, em muitos momentos. Este é um fator que pode explicar o motivo de, por muitas vezes, os anseios da indústria serem compatíveis com os do governo (ao sinalizar "convergência" nas Pautas Mínimas) nas proposições selecionadas, corroborados pelo teor dos discursos de alguns parlamentares governistas, acessíveis no anexo deste estudo. O fato de o governo estar sendo bem avaliado faz com que os 
empresários tendem a aumentar sua proximidade principalmente com os parlamentares da base governista, maximizando a probabilidade de investimento eleitoral nestes nomes (SAMUELS, 2001; LEMOS, MARCELINO, PEDERIVA， 2010; MEZZARANA, 2011 apud MANCUSO; SPECK, 2015), o que explica a eleição de um maior número de deputados governistas na amostra selecionada, em face aos deputados oposicionistas, embora o financiamento destinado àqueles tenha sido menor em números, conforme sinalizado pelo Capítulo 3.

É inegável a força de influência da indústria, no processo de produção legislativa no Brasil. Seja como um grupo de influência organizado, por meio da CNI, ou via representação direta. Além disso, cabe ressaltar que cada vez mais se elegem parlamentares que representam a indústria e menos os trabalhadores, talvez pelo fato de as representações sindicais não serem atores que participam ativamente do financiamento de campanhas eleitorais no Brasil (SAMUELS, 2006). Apesar do peso da representação direta dos interesses setoriais, o background do parlamentar (ser um parlamentar da indústria) mostrou-se como fator relevante em algumas configurações, mas não em outras, assim como fazer parte da Frente Parlamentar da Indústria. Esse fato sugere, assim como confirmou o estudo de Santos et al. (2015), que o financiamento de campanhas de origem industrial pode, também, ser entendido tanto como um mecanismo de reforço da garantia de defesa dos interesses setoriais, bem como funcionar como um indicador do autofinanciamento, uma vez que, de acordo com a legislação eleitoral brasileira, o candidato é responsável pela sua própria arrecadação de recursos de campanha.

Ao se estudar a relação entre dinheiro e comportamento parlamentar, aparentemente uma única parcela da equação se esclarece: as razões pelas quais o candidato necessita das contribuições de campanha. Porém, as motivações que movem os financiadores ainda é uma questão que permanece nebulosa. Eis uma reflexão reportada por vários autores: o que, de fato, motiva os doadores? Quais interesses tentam influenciar mais a política no Brasil por meio do financiamento de campanhas? (FRANCIA; HERRNSON; GREEN; POWELL, 2003; SAMUELS, 2006). Para além de se estudar o comportamento do parlamentar sob o constrangimento da doação de campanha, é necessário estudar, em paralelo, a atuação dos grupos de pressão e de interesse enquanto financiadores de campanha. 
Não se pretendeu, portanto, defender que o financiamento de campanhas fosse o único fator interveniente no comportamento dos deputados que acompanharam o posicionamento da indústria. Porém, apesar dos fatores complementares que podem influenciar a atuação parlamentar, fica claro que o tipo de financiamento de campanhas que os deputados recebem influencia, evidentemente, em seu modus operandi congressual, independentemente de posicionamento ideológico ou do seu background. As contribuições de origem empresarial, deste modo, impactaram positivamente o comportamento parlamentar, ao acompanharem o posicionamento da CNI nas proposições sinalizadas como de interesse máximo ao setor, embora analisado sob a lógica da multicausalidade.

Diferentemente de países como os Estados Unidos, onde tanto a legislação quanto a literatura que tratam da relação entre financiamento de campanhas e comportamento parlamentar se encontram em um estágio bastante avançado, o Brasil ainda carece de estudos empíricos que tratam desta discussão. A agenda de pesquisa é vasta; porém, diversos são os entraves para a realização de pesquisas deste porte, principalmente no tocante ao acesso aos dados.

A presente dissertação intentou, sob uma vertente metodológica ainda pouco utilizada pela literatura de Ciência Política brasileira, contribuir com o avanço dos estudos sobre dinheiro e comportamento parlamentar no Brasil. A ingerência do poder econômico na atividade política para a maximização de vantagens pós-eleitorais, assim como os questionamentos sobre o que, especificamente, o dinheiro oriundo de financiamento de campanhas é capaz de comprar no mercado político, fazem parte de frutíferos debates metodológicos que serão tratados em estudos posteriores. 


\section{7 - REFERÊNCIAS BIBLIOGRÁFICAS}

AGUIAR, Osmar de Oliveira. Os atores-chave no processo decisório no âmbito das comissões permanentes. E-Legis-Revista Eletrônica do Programa de Pós-Graduação da Câmara dos Deputados, v. 12, n. 12, p. 137-152, 2013.

ANSOLABEHERE, Stephen; DE FIGUEIREDO, John M.; SNYDER, James M. Why is there so little money in politics? National bureau of economic research, 2003.

ARAÚJO, Suely Mara Vaz Guimarães; SILVA, Rafael Silveira. Titulares da agenda e carreiras políticas. Revista Brasileira de Ciência Política, (10), 285-311, 2013.

ARAÚJO, Suely Mara Vaz Guimarães; TESTA, Graziela Guiotti; SILVA, Rafael Silveira. Fugindo do líder e caindo na rede: caminhos alternativos das demandas sociais no congresso nacional. Lima: $8^{\circ}$ encontro da Associação Latinoamericana de Ciência Política, 2015.

BOAS, Taylor C.; HIDALGO, F. Daniel; RICHARDSON, Neal P. The spoils of victory: campaign donations and government contracts in Brazil. Helen Kellogg Institute for International Studies, 2011.

BORGES, Tiago D. P. Os partidos políticos e o financiamento empresarial das campanhas legislativas para a Câmara dos Deputados: Um estudo sobre as doações empresariais e as carreiras nas eleições de 2006. Águas de Lindóia: $36^{\circ}$ Encontro Anual da Anpocs, 2012.

BRESSER-PEREIRA, Luiz Carlos. Empresários, o governo do PT e o desenvolvimentismo. Revista de Sociologia e Política, v. 21, n. 47, p. 21-30, 2013.

CABRAL, Eugênia Rosa. Articulação de interesses do empresariado industrial no processo de produção da regulação ambiental: convergências e divergências. Tese de Doutorado. Tese (Doutorado em Ciências Humanas: sociologia e política). Universidade Federal de Minas Gerais, 2007.

CLAWSON, Dan. Politics is money. Actes de la recherche en sciences sociales, v. 138, n. 3, p. 34-46, 2001.

CORADINI, Odaci Luiz. Frentes parlamentares, representação de interesses $e$ alinhamentos políticos. Revista de Sociologia e Política, v. 18, n. 36, p. 241-256, 2010.

COUTINHO. Carlos Nelson. Representação de interesses, formulação de políticas e hegemonia. In: TEIXEIRA, Fleury S. Reforma sanitária: em busca de uma teoria. São Paulo: Cortez, 1995. 
DE AZEVEDO, Sérgio; ANASTASIA, Fátima. Governança, "accountability" $e$ responsividade. Revista de Economia Política, v. 22, n. 1, p. 85, 2002.

DINIZ, Eli. Empresariado industrial, representação de interesses e ação política: trajetória histórica e novas configurações. Política e Sociedade, v. 9, n. 17, p. 101-121, 2010.

DINIZ, Eli; BOSCHI, Renato. Olha o empresariado aí, minha gente! Revista Insight, 2002.

EVANS, Diana. Oil PACs and Aggressive Contribution Strategies. The Journal of Politics, 50, pp 1047-1056, 1988.

FENNO, Richard F. Home style: House members in their districts. Boston: Little, Brown, 1978.

FIGUEIREDO FILHO, Britto et al. O elo corporativo? Grupos de interesse, financiamento de campanha e regulação eleitoral. Tese de Doutorado: Universidade Federal de Pernambuco, 2009.

FIGUEIREDO, Argelina Cheibub; LIMONGI, Fernando. Mudança constitucional, desempenho do Legislativo e consolidação institucional. Revista Brasileira de Ciências Sociais, v. 10, n. 29, p. 175-200, 1995.

FLEISCHER, David. Reforma Política e Financiamento das Campanhas Eleitorais. Cadernos Adenauer, n.10, 2000.

FRANCIA, Peter L.; HERRNSON, Paul S; GREEN, John C.; POWELL, Lynda W. The Financiers of Congressional Elections: Investors, Ideologues, and Intimates. Columbia University Press, 2003.

FREITAS, Vítor Eduardo; BIZZARRO NETO, Fernando Augusto. Qualitative Comparative Analysis (QCA): usos, possibilidades e limites para a análise da dinâmica da competição eleitoral no Brasil pós-1994. Brasília: IX Encontro da ABCP, 2014.

GERBER, Alan S. Does campaign spending work? Field experiments provide evidence and suggest new theory. American Behavioral Scientist, v. 47, n. 5, p. 541-574, 2004.

HIROI, Taeko; RENNÓ, Lucio. Obstrução e processo decisório na Câmara dos Deputados: 1991 a 2010. Brasília: IPEA, 2014.

JACOBSON, Gary C. Measuring campaign spending effects in US House elections. In: Capturing campaign effects, p. 199-220, 2006. 
The effects of campaign spending in congressional elections. American Political Science Review, v. 72, n. 02, p. 469-491, 1978.

The effects of campaign spending in House elections: New evidence for old arguments. American Journal of Political Science, p. 334-362, 1990.

LANGBEIN, Laura I. Money and access: Some empirical evidence. The journal of politics, v. 48, n. 04, p. 1052-1062, 1986.

LEMOS, Leany Barreiro; MARCELINO, Daniel; PEDERIVA, João Henrique. Porque dinheiro importa: a dinâmica das contribuições eleitorais para o Congresso Nacional em 2002 e 2006. Opinião Pública, v. 16, n. 2, p. 366-393, 2010.

MACHADO, Marcela. Doação ou investimento? A atuação legislativa dos parlamentares da bancada ruralista e a questão do financiamento de campanhas. Monografia (Graduação) - Universidade de Brasília, Instituto de Ciência Política, Brasília, 2013.

MANCUSO, Wagner P; SPECK, Bruno W. Financiamento empresarial e desempenho eleitoral no Brasil: um estudo das eleições para deputado federal em 2010. Texto apresentado no VIII Workshop Empresa, Empresários e Sociedade, Curitiba, 2012.

Financiamento empresarial na eleição para deputado federal (2002-2010): determinantes e consequências. Revista Teoria \& Sociedade, $\mathrm{n}^{\circ}$ 23.2, 2015.

O financiamento político nas eleições brasileiras de 2010: um panorama geral. Caxambu: $35^{\circ}$ Encontro Anual da Anpocs, 2011.

MANCUSO, Wagner Pralon. O empresariado como ator político no Brasil: balanço da literatura e agenda de pesquisa. Revista de Sociologia e Política, v. 28, p. 131-146, 2007.

O lobby da indústria no Congresso Nacional: empresariado e política no Brasil contemporâneo. Dados, v. 47, n. 3, p. 505-547, 2004.

MARENCO, André. Quando Leis Não Produzem os Resultados Esperados: Financiamento Eleitoral em Perspectiva Comparada. DADOS - Revista de Ciências Sociais, Rio de Janeiro, vol. 53, nº 4, pp. 821 a 853, 2010.

MENEGUIN, F. B.; MAGNA, I. Desempenho do Poder Legislativo: como avaliar? Brasília: Núcleo de Estudos e Pesquisas/CONLEG/Senado, Setembro/ 2014 (Texto para Discussão $\left.\mathrm{n}^{\circ} 155\right)$. 
PEIXOTO, Vitor de Moraes. Votos: Valem quanto pesam? O Impacto do Financiamento de Campanhas Eleitorais no Brasil. Dissertação de Mestrado em Ciência Política, IUPERJ, 2004.

Financiamento de campanhas: o Brasil em perspectiva comparada. São Paulo: Perspectivas, v. 35, p. 91-116, jan./jun. 2009.

PEREIRA, Carlos; RENNÓ, Lúcio. O que é que o reeleito tem? O retorno: o esboço de uma teoria da reeleição no Brasil. Rev. Econ. Polit., São Paulo, v. 27, n. 4, 2007.

PEREIRA, Carlos; POWER, Timothy e RENNÓ, Lúcio. Under what conditions do presidents resort to decree power? Theory and evidence from the Brazilian case. Journal of Politics, v. 67, n. 1, p. 178-200, 2005.

PERES, Paulo; CARVALHO, Ernani. Religando as arenas institucionais: uma proposta de abordagens multidimensionais nos estudos legislativos. Rev. Sociol. Polit.[online]. Vol.20, n.43, pp. 81-106, 2012.

RAGIN, Charles C. Redesigning Social Inquiry: Fuzzy Sets and Beyond. Chicago: University of Chicago Press, 2008.

User's Guide to Fuzzy-Set/Qualitative Comparative Analysis 2.0.

Tucson, Arizona: Department of Sociology, University of Arizona, 2008a.

SABATO, Larry. PAC power: Inside the world of political action committees. New York: Norton, 1985.

SAMUELS, David. Does Money Matter? Credible Commitments and Campaign Finance in New Democracies: Theory and Evidence from Brazil. In: Comparative Politics, Vol. 34, No. 1 (Oct., 2001), pp. 23-42.

Incumbents and challengers on a level playing field: assessing the impact of campaign finance in Brazil. The journal of Politics, v. 63, n. 02, p. 569$584,2001$.

Financiamento de campanhas no Brasil e proposta de reforma. In: Reforma política: lições da história recente. Rio de Janeiro: Editora FGV, p. 133153, 2006.

SANTOS, Manoel Leonardo; SILVA, Mariana Batista da; FIGUEIREDO FILHO, Dalson Britto Figueiredo e ROCHA, Enivaldo Carvalho da. Financiamento de campanha e apoio parlamentar à Agenda Legislativa da Indústria na Câmara dos Deputados. Opinião Pública [online]. Vol.21, n.1, pp. 33-59, 2015. 
SANTOS, Manoel Leonardo. Representação de interesses na arena legislativa: os grupos de pressão na Câmara dos Deputados (1983-2012). Rio de Janeiro: IPEA, 2014.

SANTOS, Rafael Freitas. Poder de agenda e participação legislativa no presidencialismo de coalizão brasileiro. Dissertação de Mestrado, Universidade de São Paulo, 2010.

SANTOS, Rodrigo Dolandelli. Grandes Empresários e Sucesso Eleitoral nas eleições de 2002, 2006 e 2010. Águas de Lindóia: 36 Encontro Anual da Anpocs, 2012.

SCHNEIDER, Carsten Q.; ROHLFING, Ingo. Combining QCA and process tracing in set-theoretic multi-method research. Sociological Methods \& Research, v. 42, n. 4, p. 559-597, 2013.

SCHNEIDER, Carsten Q.; WAGEMANN, Claudius. Standards of good practice in qualitative comparative analysis (QCA) and fuzzy-sets. Comparative Sociology, v. 9, n. 3, p. 397-418, 2010.

SILVA, Rafael Silveira. Construindo e gerenciando estrategicamente a agenda legislativa do Executivo: o fenômeno da Apropriação. Tese (Doutorado). Universidade de Brasília, Instituto de Ciência Política, Brasília, 2013.

SPECK, Bruno. A responsabilidade das empresas no processo eleitoral - Edição 2014. São Paulo: Ethos, 2014.

O financiamento de partidos e campanhas eleitorais nos Estados Unidos: uma aproximação descritiva. Estudos de Análise e Conjuntura - $\mathrm{N}^{\mathrm{o}} 2$, Novembro de 2010.

THOMAZ, Laís Forti. O lobby do etanol na definição da política agrícola dos EUA (2002-2011). São Paulo: Editora UNESP, 2012.

TRIBUNAL SUPERIOR ELEITORAL. Cartilha sobre a prestação de contas das Eleições 2014. - Brasília: Tribunal Superior Eleitoral, 2014. 45 p.; 14,8 cm. Disponível em: $\quad$ http://www.justicaeleitoral.jus.br/arquivos/tse-cartilha-prestacao-de-contaseleicoes-2014. Acesso em 16/12/2015.

Manual técnico de arrecadação e aplicação de recursos e de prestação de contas: eleições 2010. - Brasília: Tribunal Superior Eleitoral, 2010.36 p.; $21 \mathrm{~cm}$. Disponível em: http://www.tse.jus.br/arquivos/tse-manualtecnico-de-arrecadacao-e-aplicacao-de-recursos-e-de-prestacao-de-contas. Acesso em $\underline{16 / 12 / 2015 .}$ 
WAWRO, Gregory. A panel probit analysis of campaign contributions and roll-call votes. American Journal of Political Science, p. 563-579, 2001. 
ANEXOS 


\section{CÂMARA DOS DEPUTADOS - DETAQ}

Sessão: $049 \cdot 3 \cdot 54.0$

Hora: $16 \mathrm{~h} 27$

Fase: PE

Orador: PAES LANDIM PTB-PI

Data: 01/04/2013

\section{Sumário}

Alto custo de operação dos portos brasileiros. Acerto da edição da Medida Provisória no 595, de 2012, sobre a criação do novo marco regulatório do sistema portuário nacional. Artigo A indústria apoia a MP 595, que regula o setor portuário, de Robson Braga de Andrade, publicado pelo jornal Valor Econômico.

O SR. PAES LANDIM (PTB-PI. Como Líder. Com revisão do orador.) - Sr. Presidente, o jornal Folha de S.Paulo do último dia 26 de março traz uma notícia impactante. Um manobrista de navio no Brasil, o chamado prático, ganha até 80 mil reais por mês, fazendo com que o sistema portuário brasileiro seja um dos mais caros do mundo, elevando o Custo Brasil.

Veja, Sr. Presidente, a razão por que o Brasil é um dos países que tem o maior custo na operação dos nossos portos pluviais e marítimos; com certeza, aumentando o Custo Brasil e obstaculizando a inserção do País no quadro da competitividade internacional.

A respeito disso, aliás, este excepcional Presidente da Confederação Nacional da Indústria, Robson Braga de Andrade, num belo, conciso e profundo artigo escrito no jornal Valor Econômico do mesmo dia, 26 de março, sob o título A indústria apoia a MP 595 que regula o setor portuário, mostra que o tempo para se atracar um navio no Brasil é muito superior à média mundial.

Ele inicia o seu artigo assim dizendo:

"Os portos estão entre os principais entraves na cadeia logística brasileira. Sua baixa eficiência e saturação vêm comprometendo a competitividade da nossa economia há vários anos. No último ranking do Fórum Econômico Mundial, publicado em setembro de 2012, 0 Brasil figura entre os dez piores desempenhos em qualidade da infraestrutura portuária nos 144 países analisados."

E a sua conclusão, nos seus dois últimos parágrafos, Sr. Presidente, merece realmente reflexão e mostra um grande acerto na medida tomada pela Presidenta Dilma Rousseff, uma decisão de estadista, ao tentar modernizar o sistema portuário brasileiro.

Assim diz Robson Andrade, no seu artigo:

"Dessa forma, é preciso apagar o passado para recriar no Brasil um clima favorável aos investimentos privados do setor portuário. Com a MP no 595, perdem alguns poucos grupos que se beneficiavam com o fechamento do mercado portuário ao investimento privado, e ganham o setor produtivo e a sociedade brasileira.

Ao se insurgirem contra a MP, alguns trabalhadores portuários trabalham contra o crescimento econômico sustentado e, em grande medida, contra seus próprios interesses. $A$ indústria nacional apoia fortemente a edição da medida provisória e vai lutar pela sua aprovação, necessária para o aumento dos investimentos da economia brasileira, a dinamização do comércio exterior, a elevação do nível de emprego e o pleno desenvolvimento dopaís." 
Sr. Presidente, o artigo do eminente Presidente da CNI, Robson Andrade, deveria ser lido por todos os Parlamentares, que deveriam também refletir sobre ele, porque, realmente, reflete o espírito de um país moderno, competitivo. E esse artigo mostra exatamente a justeza da Sra. Presidenta Dilma Rousseff ao editar a Medida Provisória no 595, porque ela vem já com muito atraso tentar espancar de vez um grande atraso que o Brasil tem no seu sistema portuário.

É uma pena que os defensores da modernização do Brasil não se tenham empenhado por uma proposta fundamental, visto que, sem a modernização dos portos brasileiros, cuja operação é das mais caras do mundo, nós não temos como competir no mercado internacional.

A medida provisória vem atender a uma necessidade urgente do Brasil real. $\mathrm{O}$ artigo de Robson Andrade mostra exatamente a grande medida de estadista tomada pela Presidenta Dilma Rousseff ao editar a Medida Provisória no 595.

Em razão disso, Sr. Presidente, peço a atenção de V.Exa. e requeiro a transcrição nos Anais desta Casa do artigo do eminente Presidente da Confederação Nacional da Indústria, Robson Andrade, publicado no Valor Econômico.

Muito obrigado, Sr. Presidente, pela atenção.

\section{ARTIGO A QUE SE REFERE O ORADOR}

A indústria apoia a MP 595 que regula setor portuário Por Robson B. de Andrade

O comércio exterior brasileiro dobrou nos últimos dez anos, mas nossos portos continuam os mesmos

Os portos estão entre os principais entraves na cadeia logística brasileira. Sua baixa eficiência e saturação vêm comprometendo a competitividade da nossa economia há vários anos. No último ranking do Fórum Econômico Mundial, publicado em setembro de 2012, o Brasil figura entre os dez piores desempenhos em qualidade da infraestrutura portuária nos 144 países analisados. O tempo de espera para atracar um navio nos portos daqui é muito superior à média do mercado internacional.

Nossos portos são caros. Uma pesquisa do Fórum Nacional da Indústria que avaliou a opinião de 45 grandes líderes empresariais identificou o setor portuário como prioridade de ação para a agenda da competitividade da indústria brasileira. Existe uma explicação para esse fato: o comércio exterior brasileiro dobrou nos últimos dez anos - $94 \%$ do fluxo passa pelos portos, mas eles continuam praticamente os mesmos.

Em volume, 571 milhões de toneladas foram movimentadas pelos portos nacionais em 2003. No ano passado, esse montante chegou a cerca de 900 milhões de toneladas. Foram acrescentados à movimentação aproximadamente 33 milhões de toneladas por ano. Mas o espaço dedicado para carga, descarga e armazenamento das mercadorias cresceu muito pouco, menos que $5 \%$. Poucas áreas novas importantes foram agregadas ao sistema portuário nos últimos anos. Vale citar o terminal privado de Itapoá, em Santa Catarina, e a licitação do terminal público de grãos de São Luís, projeto em elaboração há mais de 10 anos.

No entanto, o aumento da eficiência portuária por meio de equipamentos mais modernos e de novas técnicas de gerenciamento esbarra num limite técnico, que é o espaço físico para a movimentação das mercadorias. A equação é simples: carga crescente mais falta de novas áreas para movimentação igual a congestionamento mais aumento de custos.

A Medida Provisória no 595 foi editada em dezembro do ano passado para reverter esse quadro e eliminar uma série de barreiras ao investimento privado no setor. Dentre outros dispositivos, a MP acaba com a distinção entre carga própria e de terceiros, motivo de acirrada disputa comercial entre operadores portuários públicos e privados. Esse verdadeiro embate comercial, que se iniciou no mercado de contêineres, acabou contaminando todo o 
sistema portuário nacional e afastou os investimentos em novos terminais.

A MP dá segurança jurídica aos 130 terminais privados em operação e libera novos investimentos nesses terminais, independentemente da carga a ser movimentada. Assim, caminhamos na direção da prática das principais potências do comércio exterior mundial, onde não existe diferenciação entre os tipos de carga a ser movimentada.

As novas regras para os terminais privados proíbem a sua construção dentro da área do porto organizado, visando solucionar o problema da provável assimetria de custos entre os dois tipos de instalações (de uso público e de uso privado). Os terminais privados já autorizados, mesmo quando situados dentro da área do porto organizado, têm sua continuidade assegurada. Cumprir contratos é a regra de ouro para ganhar a confiança do investidor.

Os terminais privados também ganharam maior segurança jurídica após a autorização de funcionamento poder ser prorrogada por períodos sucessivos, eliminando possíveis problemas do investidor privado no futuro.

Outro avanço importante foi a definição de porto organizado como um "bem público" construído e aparelhado para atender às necessidades de navegação, movimentação de passageiros e mercadorias. Quando os terminais são licitados, o administrador privado passa a ter direito de uso de uma área pública do porto organizado e não mais delegação da prestação do serviço, liberando o investidor das responsabilidades referentes à prestação desse tipo de serviço.

A MP 595 também revoga a antiga Lei dos Portos (Lei no 8.630/93), que foi muito importante na década de 1990 para organizar e possibilitar profundas transformações no setor. Mas a lei estava desatualizada e deu margem aos sérios problemas que vivemos hoje no segmento.

Com a revogação da Lei no $8.630 / 93$, as fortes restrições ao investimento privado contidas no Decreto no 6.620/2008 e na Resolução Antaq no 1.695/10 caíram por terra. Duas ações em andamento no Supremo Tribunal Federal (STF) perderam o sentido, em especial a Arguição de Descumprimento de Preceito Fundamental (ADPF) no 139, proposta pela Associação Brasileira de Terminais Públicos de Contêineres contra a agência reguladora do setor, pelo fato de ela ter autorizado a operação de terminais privados.

Esses atos legais (decreto e resolução), em conjunto com as ações em andamento no STF, constituíam uma barreira quase intransponível ao investimento privado. O "espírito animal" do investidor não costuma se manifestar em um ambiente institucional confuso e inseguro. Dessa forma, é preciso apagar o passado para recriar no Brasil um clima favorável ao investimento privado no setor portuário. Com a MP o5 595, perdem alguns poucos grupos que se beneficiavam com o fechamento do mercado portuário ao investimento privado, e ganham o setor produtivo e a sociedade brasileira.

Ao se insurgirem contra a MP, alguns trabalhadores portuários trabalham contra o crescimento econômico sustentado e, em grande medida, contra seus próprios interesses. A indústria nacional apoia fortemente a edição da medida provisória e vai lutar pela sua aprovação, necessária para o aumento dos investimentos na economia brasileira, a dinamização do comércio exterior, a elevação do nível do emprego e o pleno desenvolvimento do país. 


\section{CÂMARA DOS DEPUTADOS - DETAQ}

Sessão: $160.3 \cdot 54.0$

Hora: $16 \mathrm{~h} 46$

Fase: PE

Orador: FABIO TRAD PMDB-MS

Data: $11 / 06 / 2013$

\section{Sumário}

Causas da queda da competitividade da indústria brasileira. Aprovação pela Casa da Medida Provisória $\mathrm{n}^{0}$ 595, de 2012, sobre o estabelecimento do novo marco regulatório do setor portuário nacional.

O SR. FABIO TRAD (PMDB-MS. Sem revisão do orador.) - Sr. Presidente, Sras. e Srs. Deputados, falo sobre a competitividade brasileira, um assunto tormentoso, que vem galvanizando a atenção da opinião pública do País.

Em geral, a merecida insistência sobre a falta de competitividade do Brasil se manifesta pelo desfiar de números, de índices e indícios que, pela sua própria exorbitância, acabam mal digeridos, prestando-se mais a sugerir uma macunaímica impotência do País para desatar os nós que nos amarram ao atraso.

O pior é que as referências confiáveis sustentam uma das raras unanimidades nacionais: o Brasil está entalado no gargalo de um longo impasse competitivo, que se materializa nos transportes e em todos os demais setores estratégicos.

Menos que rememorar números do tristemente célebre Custo Brasil, quero chamar a atenção para o déficit de compromisso com que esse grave e crônico entrave tem sido tratado nos últimos dias.

Poderia ser só uma amarga ironia que a Medida Provisória no 595, de 2012, a tão mareada Medida Provisória dos Portos, quase tenha encalhado nesta Casa. Porém, foi muito mais que isso. O conflito de interesses provocou o que S.Exa. o Presidente Henrique Eduardo Alves lamentou como episódio execrável, jamais visto em sua longa carreira parlamentar.

Ainda assim, sempre tive e tenho a mais inarredável convicção de que este Plenário jamais seria o banco de areia da intransigência, onde a MP dos Portos naufragaria inapelavelmente. Contudo, o déficit de competitividade do Brasil não está, infelizmente, só nos portos públicos, hoje loteados a exploradores privados que "não querem concorrência", como disse a Ministra Gleisi Hoffmann, da Casa Civil.

O Custo Brasil, que nos rouba energia competitiva, está também na indústria, que, mesmo rebocada por pacotes bilionários de incentivo, segue perdendo espaço para concorrentes, tanto no mercado externo como dentro de casa.

A indústria brasileira recebe proteção do Governo, mas, ao contrário do que ocorre em outros países, não precisa cumprir exigências para melhorar o desempenho.

Para o renomado economista Luiz Gonzaga Belluzzo, o Governo deve adotar uma política de ganho de competitividade, inclusive com redução de lucro. Muitos especialistas apontam que a receita para o País avançar em competitividade está em diminuir a rentabilidade, em benefício de melhor remuneração da mão de obra.

Um dos argumentos favoráveis à proposta está em pesquisa da Universidade de Princeton, nos Estados Unidos: enquanto, no Brasil, um funcionário do McDonald's compra meio Big Mac com o que ganha em uma hora de trabalho, seu equivalente japonês pode comer três Big 
Macs com o fruto do mesmo esforço.

Assim, o déficit de competitividade industrial do Brasil não pode ser financiado indefinidamente pelo contribuinte, através das sempre renovadas isenções de IPI, agregadas a crédito subsidiado e a outras facilidades para a indústria automobilística, a de eletrodomésticos, etc.

Aliás, não por outra razão, o empresariado brasileiro está sempre pronto a apontar os gargalos de logística e de transportes, além da burocracia estatal, como causas exclusivas do Custo Brasil. Socorridos a cada grita, para eles, a falta de competitividade é um problema do Governo.

Muito obrigado. 


\section{CÂMARA DOS DEPUTADOS - DETAQ}

Sessão: 081.3.54.O

Hora: $15 \mathrm{~h} 16$

Fase: BC

Orador: MAURO BENEVIDES PMDB-CE

Data: $23 / 04 / 2013$

\section{Sumário}

Divulgação da Agenda Legislativa de 2013 da Confederação Nacional da Indústria - CNI. Atenção dispensada pelo setor industrial ao Projeto de Lei Complementar $\mathrm{n}^{0}$ 200, de 2012, a respeito de extinção da contribuição social.

O SR. MAURO BENEVIDES (PMDB-CE. Sem revisão do orador.) - Sr. Presidente, Sras. e Srs. Deputados, a exemplo do que ocorre, anualmente, a Confederação Nacional da Indústria, presidida por Robson Andrade, divulgou, ao meio-dia de hoje, a Agenda Legislativa de 2013, consubstanciando aquelas proposições que mais de perto interessam ao País e que dependem da manifestação das duas Casas integrantes do Congresso e, logo depois, da sanção da Presidente da República Dilma Rousseff, atenta a temas dessa magnitude.

Sabemos que foram listadas cerca de 130 propostas em tramitação no nosso Parlamento, com informação precisa de sua repercussão para o empresariado brasileiro.

O Poder Executivo, através do Ministério da Fazenda, persiste, no corrente exercício, no propósito de continuar propiciando desonerações tributárias, como forma de impulsionar a expansão de nossas atividades produtivas.

Portanto, Sr. Presidente, é um acontecimento importante que me permiti registrar. Se não fora esse compromisso no plenário, nós estaríamos então para ouvir a exposição do Presidente Robson Andrade sobre essas prioridades legislativas para aquele órgão.

\section{PRONUNCIAMENTO ENCAMINHADO PELO ORADOR}

Sr. Presidente, Sras. e Srs. Deputados, a exemplo do que ocorre, anualmente, a Confederação Nacional da Industria, presidida por ROBSON ANDRADE, divulgou, ao meio dia de hoje, a Agenda Legislativa de 2013, consubstanciando aquelas proposições que mais de perto interessam ao País e que dependem da manifestação das duas Casas integrantes do Congresso Nacional e, logo depois, da sanção da Presidente da República Dilma Rousseff, atenta a temas dessa magnitude.

Sabe-se que foram listadas cerca de 130 propostas em tramitação no nosso Parlamento, com informação precisa de sua repercussão para o empresariado brasileiro, num momento em que se busca ampliar as alternativas capazes de contribuir para a elevação do Produto Interno Bruto, já que o percentual do ano passado resultou frustrante, calculado em apenas $0,9 \%$, apesar da adoção, na época, de procedimentos estimuladores de um bem melhor posicionamento.

O Poder Executivo, através do Ministério da Fazenda, persiste, no corrente exercício, no propósito de continuar propiciando desonerações tributárias, como forma de impulsionar a expansão de nossas atividades produtivas, de molde a que possamos chegar a 3,5\% 
recuperando o prestígio diante dos importantes parceiros no G-20, que congrega sólidas potências universais.

Sabe-se que a maior atenção dos industriais direciona-se para o Projeto de Lei Complementar no 200, de 2012, que trata da extinção da contribuição social de multa adicional de $10 \%$ do FGTS, devida pelos empregadores em caso de demissão sem justa causa. Como setor vital para a recuperação de nosso desenvolvimento, a indústria tem enfrentado dificuldades decorrentes da própria conjuntura, cabendo ao Poder Central colaborar para o surgimento de um segmento decisivo para a vitalização do nosso progresso e bem-estar social.

Todos os Senadores e Deputados foram convidados para o evento, a fim de que, assim, se conscientizem da necessidade de oferecer prioridade às iniciativas que mais de perto interessam ao nosso País.

Predispomo-nos a acolher as ponderações da atuante $\mathrm{CNI}$, na certeza de que se contribuirá, desta forma, para incentivar o crescimento do próprio País, na superação desta fase delicada por que passa a nossa Nação, apesar da diligente atuação de uma gestora competente, como a que dirige os nossos destinos, com aprumo e clarividência inquestionáveis. 


\section{CÂMARA DOS DEPUTADOS - DETAQ}

Sessão: $278 \cdot 3 \cdot 54.0$

Orador: MAURO BENEVIDES PMDB-CE

\section{Sumário}

Expectativa quanto à apreciação, pelo Congresso Nacional, do veto presidencial aposto ao projeto de lei complementar sobre a extinção da cobrança da multa de $10 \%$ sobre o saldo do Fundo de Garantia do Tempo de Serviço - FGTS em caso de demissão sem justa causa.

O SR. MAURO BENEVIDES (PMDB-CE. Pela ordem. Pronuncia o seguinte discurso.) - Sr. Presidente, conforme fora acertado entre os Presidentes das duas Casas do Parlamento, deverá realizar-se, amanhã, sessão especial do Congresso, destinada à apreciação de vetos presidenciais, incidentes sobre matérias enviadas com a recusa do Executivo, que utiliza para tanto prerrogativa que Ihe é definida pela Carta Magna.

$\mathrm{Na}$ última dessas deliberações, não se registrou a recusa de nenhuma das proposições vetadas pela Primeira Magistrada, numa articulação conduzida por partidos da base aliada, apesar da mobilização dos segmentos envolvidos, muito bem sintonizados com grupos de pressão legítima sobre os membros do Senado e da Câmara dos Deputados.

Uma das matérias mais controvertidas continua a ser a multa do FGTS, com o posicionamento pela rejeição endossado por entidades empresariais, através de seus órgãos mais representativos, inclusive a poderosa Confederação Nacional da Indústria, presidida pelo líder Robson Braga de Andrade.

É muito provável que o comparecimento, nesta terça-feira, possa ser dos mais significativos, em razão também de outros itens que serão submetidos ao crivo final e decisivo dos legítimos representantes populares.

Já hoje os envolvidos far-se-ão presentes ao Distrito Federal para proceder aos contactos com os nossos colegas, cada qual apresentando razões que justificariam a rejeição dos aludidos vetos.

A sistemática regimental até aqui seguida é a do voto secreto, embora deliberação recente deste augusto Plenário haja sido pelo voto aberto, faltando, ainda, para sua implantação, o indispensável pronunciamento dos integrantes do Senado Federal.

Muitos outros itens comporão o rol dos temas selecionados, devendo as cédulas ser confeccionadas pela Gráfica do Senado, com orientação do PRODASEN, cujo quadro de servidores é dos mais qualificados na estrutura congressual.

Por ser secreto, ninguém arrisca prognóstico a respeito, embora as lideranças governamentais considerem tranquila a preservação da recusa da Titular do Planalto.

Muito obrigado, Sr. Presidente. Muito obrigado, Sras. e Srs. Deputados aqui presentes. 